Cronkleton, P. et al.

Environmental Governance and the Emergence of Forest-Based Social Movements/

by Peter Cronkleton, Peter Leigh Taylor, Deborah Barry, Samantha Stone-Jovicich, Marianne Schmink.

Bogor, Indonesia: Center for International Forestry Research (CIFOR), 2008.

ISSN 0854-9818

ISBN: 978-979-1412-43-8

iv+36p. (CIFOR Occasional Paper No. 49)

CABI thesaurus: 1. community forestry 2. conservation 3. protected areas 4. social participation 5. grassroots organizations 6. community action 7. Guatemala 8. Nicaragua 9. Brazil 10. Amazonia 11. Central America 12. Latin America

(C) 2008 by Center for International Forestry Research

All rights reserved

Printed by SMK Grafika Desa Putera, Jakarta

Cover photos by Peter Cronkleton and Peter Leigh Taylor

Published by Center for International Forestry Research Mailing address: P.O. Box 0113 BOCBD, Bogor 16000, Indonesia Office address: JI. CIFOR, Situ Gede, Bogor Barat 16115, Indonesia Tel.: +62 (251) 622622; Fax: +62 (251) 622100

E-mail: cifor@cgiar.org

Web site: http://www.cifor.cgiar.org 


\section{Environmental Governance and the Emergence of Forest-Based Social Movements}

Peter Cronkleton ${ }^{1}$

Peter Leigh Taylor ${ }^{2}$

Deborah Barry ${ }^{3}$

Samantha Stone-Jovicich ${ }^{4}$

Marianne Schmink ${ }^{4}$ 


\section{Contents}

Abbreviations and Acronyms iii

Acknowledgements iv

Abstract iv

1. Forest Conservation, Governance and Support to Forest Communities 1

2. The Development of Forest-based Grassroots Movements and Models of External Technical Support

2.1 Communities and Forest Concessions in the Petén, Guatemala: The Case of ACOFOP

2.2 The Struggle for Property Rights and Forest Livelihoods in Acre, Brazil

2.3 Farmer-to-Farmer Collaboration to Slow Forest Degradation in Siuna, Nicaragua

2.4 Collaborative Community Conservation and Sustainable Forest Management in Mamirauá, Brazil

3. Common patterns in the emergence of forest-based Social Movements 25

3.1 Weak Governance on the Frontier and Threats to Livelihoods 25

3.2 Community-level Stakeholders Respond with Collective Action 26

3.3 Crucial Support from Two Types of External Assistance 26

3.4 Forest Social Movements Face New Challenges in Adapting to Changing Contexts 28

3.5 Grassroots Movements, Forest Stewardship Communities and Conservation 29

$\begin{array}{ll}\text { 4. Conclusions } & 31\end{array}$

5. References 32 


\section{Abbreviations and Acronyms}

\begin{tabular}{|c|c|}
\hline ACICAFOC & $\begin{array}{l}\text { Asociación Coordinadora Indígena Campesina de agroforestería Comunitaria } \\
\text { Centroamericana (Central American Indigenous and Peasant Coordinator of } \\
\text { Communal Agroforestry) }\end{array}$ \\
\hline ACOFOP & $\begin{array}{l}\text { Asociación de Comunidades Forestales de Petén (Association of Forest } \\
\text { Communities of the Petén) }\end{array}$ \\
\hline CAEX & Cooperativa Agro-extrativista de Xapuri (Agro-Extractive Cooperative of Xapuri) \\
\hline CEDOP & $\begin{array}{l}\text { Centro de Documentação e Pesquisa da Amazônia (Amazonian Center for Research } \\
\text { and Documentation) }\end{array}$ \\
\hline CONAP & $\begin{array}{l}\text { Consejo Nacional de Areas Protegidas (National Commission for Protected } \\
\text { Areas) }\end{array}$ \\
\hline CONTAG & $\begin{array}{l}\text { Confederação dos Trabalhadores na Agricultura (Confederation of Agricultural } \\
\text { Workers) }\end{array}$ \\
\hline CNS & Conselho Nacional dos Seringueiros (National Rubber Tappers Council) \\
\hline CNPq & $\begin{array}{l}\text { Conselho Nacional de Desenvolvimento Cientifico e Tecnológico (National Council } \\
\text { for the Development of Science and Technology) }\end{array}$ \\
\hline CTA & Centro de Trabalhadores da Amazônia (Center for Amazonian Workers) \\
\hline DFID & Department for International Development (UK) \\
\hline FYDEP & $\begin{array}{l}\text { Empresa de Fomento y Desarrollo del Petén (Promotion and Development } \\
\text { Company of the Petén) }\end{array}$ \\
\hline IBAMA & $\begin{array}{l}\text { Instituto Brasileiro do Meio Ambiente e dos Recursos Naturais Renováveis } \\
\text { (Brazilian Institute for Environment and Renewable Natural Resources) }\end{array}$ \\
\hline ICDP & Integrated Conservation and Development Programme \\
\hline IDB & Inter-American Development Bank \\
\hline IDSM & $\begin{array}{l}\text { Instituto de Desenvolvimento Sustentável Mamirauá (Mamirauá Institute of } \\
\text { Sustainable Development) }\end{array}$ \\
\hline IPAAM & $\begin{array}{l}\text { Instituto de ProteçãoAmbiental doEstado do Amazonas (Institute of Environmental } \\
\text { Protection of the State of Amazonas) }\end{array}$ \\
\hline MBR & Maya Biosphere Reserve \\
\hline MCT & Ministério da Ciência \& Tecnologia (Ministry of Science and Technology) \\
\hline MEB & Movimento de Educação de Base (Movement for Grassroots Education) \\
\hline MDA & Ministério do Desenvolvimento Agrário (Ministry of Agrarian Development) \\
\hline MUZ & Multiple Use Zone \\
\hline MMA & Ministério do Meio Ambiente (Ministry of Environment) \\
\hline MPL & $\begin{array}{l}\text { Movimento de Preservação dos Lagos Comunitários (Community Lake Preservation } \\
\text { Movement) }\end{array}$ \\
\hline NGO & Non-governmental Organization \\
\hline NTFP & Non-timber Forest Product \\
\hline $\mathrm{PCaC}$ & Programa Campesino a Campesino (Farmer-to-Farmer Programme) \\
\hline PAE & Projeto Assentamento Extrativista (Extractive Settlement Project) \\
\hline PMFSimples & $\begin{array}{l}\text { Plano de manejo florestal sustentável simplificado (Simplified plan for sustainable } \\
\text { forest management) }\end{array}$ \\
\hline PT & Partido dos Trabalhadores (Brazilian Workers' Party) \\
\hline RDSM & $\begin{array}{l}\text { Reserva de Desenvolvimento Sustentavel Mamirauá (Mamirauá Sustainable } \\
\text { Development Reserve) }\end{array}$ \\
\hline RESEX & Reserva Extrativista (Extractive reserve) \\
\hline SCM & Sociedade Civil Mamirauá (Mamirauá Civil Society) \\
\hline USAID & United States Agency for International Development \\
\hline UNAG & $\begin{array}{l}\text { Unión Nacional de Agricultores y Ganaderos (National Union of Farmers and } \\
\text { Ranchers) }\end{array}$ \\
\hline UNES & United Nations Educational, Scientific and Cultural Organization \\
\hline WCS & Wildlife Conservation Society \\
\hline
\end{tabular}




\title{
Acknowledgements
}

We are deeply indebted to the authors, researchers and others who contributed to the context studies, participatory community studies and methodological documents underlying this paper. These include Rubén Pasos, Nelda Sánchez, Paulo Amaral, Carmen Garcia, Ileana Gómez, Ernesto Méndez, Nelson Cuellar, Susan Kandel, Eduardo Baumeister, Noemi Porro, Andrea Pires, Hudson Fonseca, Patricia Roth, Magna Cunha dos Santos, Andrés Lizano, Karina Martínez, Miguel Martínez Moran, Omar Antonio Mercado Zamora, Juan Matías, Hector Aldana, Alexia Guerra Baños and Isael Recinos. We also thank the many local community leaders and members of the grassroots forest organizations whose experiences and accomplishments this project has sought to document and strengthen. We particularly want to thank Carol Colfer, Bob Fisher and Marilyn Hoskins for their insightful comments and suggestions in reviewing the paper. Many thanks also go to our editor, Rosie Ounsted, whose revisions and suggestions were crucial for finalizing this document. Finally, we are grateful to the Ford Foundation, whose generous support has made this project possible.

\begin{abstract}
This occasional paper is based on the results of a three-year project examining the emergence of forest-based grassroots movements in Latin America. Funded by the Ford Foundation, the Support to Grassroots Community Forestry Organizations in Central America and Brazil Project sought to understand how grassroots groups develop and influence conservation and development. The project focused on four noteworthy cases in Central America and Brazil, each representing 'successful' broad-based collective action to defend local control and use of forest lands. Cases included the Association of Forest Communities of the Petén in Guatemala, the Siuna Farmerto-Farmer exchange programme in Nicaragua, the Mamirauá Sustainable Development Reserve in the Brazilian state of Amazonas, and the Brazilian rubber tapper movement in Acre. Although the context and outcomes varied, in these cases grassroots collective action to defend local livelihoods emerged when initially weak government institutions attempted to counteract chaotic frontier conditions through the imposition of conservation and development initiatives, provoking local resistance. A combination of indigenous capacity for collective organization and significant external assistance helped produce grassroots forest movements capable of becoming proactive partners in the management and defence of protected areas. These groups still confront external incursions into their hard-won resources rights and strive to respond to changing membership needs. The cases suggest that local communities can become effective forest stewards when acquired rights are duly recognized, avenues exist for meaningful participation, costs and benefits are distributed fairly, and appropriate external support is provided.

Key Words: community forestry, social movements, conservation, grassroots
\end{abstract}




\section{Forest Conservation, Governance and Support to Forest Communities}

Forest-based social movements in Latin America are today helping to introduce a new conservation actor into the governance of protected areas: the forest steward community. These forest steward communities are attaining significant legal recognition of customary access and formal rights to forest resources. They form collective institutions to more proactively govern resource use and management and develop new capacities to learn and adapt to changing conditions. Forest steward communities are linked to a growing network of horizontal and vertical alliances with other groups with shared interests, enhancing their access to information and experience as well as their political influence through collective action. These communities are participating on a more equal footing in negotiations over conservation policy rather than simply appearing as recipients of external aid. They show that at the local level conservation and development need not be opposing strategies. Rather than being part of the deforestation problem, organized forest communities are potentially key allies in environmental governance protecting and managing natural resources for the future (see, for example, Klooster (2000), Taylor and Zabin (2000), Bray and Merino Pérez (2002), and Bray et al. (2005) on the importance of the Mexican experience with community-based forestry).

Why do these forest steward communities represent an important new feature of conservation and development in the region's protected areas? What conditions have led to their emergence, and how might they be supported and encouraged through external assistance? Forested regions in the developing world have historically been the object of competing resource-use claims by groups seeking to extract precious minerals, petroleum, timber or non-timber products; to access land for subsistence or commercial agriculture and ranching; and recently, to protect threatened biodiversity and cultural treasures for their intrinsic value or for the development of tourism activities. In this context of intense competition to control and protect the forest, forest-dependent people and their livelihoods are pitted against conservation or development objectives driven by economically and politically powerful interests. Frequently, local people are blamed for forest degradation, lose access to resources or are expelled outright. Sometimes, however, they respond collectively to defend their interests and maintain the forests that support their livelihoods. When such social movements occur they can strengthen governance on forest frontiers and lessen impacts of more deleterious change. This paper examines environmental governance in four cases where forest-based social movements have maintained control over forest resources, continue to base their livelihoods on forest use and, we believe, positively influenced conservation.

Environmental governance not only refers to governmental regulation and law enforcement for conservation but also involves the political, organizational and cultural frameworks through which diverse interests in natural and cultural resources are coordinated and controlled. To combat deforestation and biodiversity loss in highly threatened forests of the global South, national governments, multilateral political institutions and international conservation organizations have set up and administered protected areas, or reserves. One of the first major issues that appeared with the creation of protected areas and reserves, however, was that these lands were usually already in use by rural people and other economic interests. As they have come to recognize the complexity of the social landscape of endangered forests, many conservation organizations have sought to work closely with indigenous and traditional 
communities, often through Integrated Conservation and Development Programmes (ICDPs), which intended to compensate for some of the lost livelihood elements with market-based incomes. Nevertheless, critics of ICDPs observed that they tended to be illconceived and were carried out by conservation organizations unprepared to work in social and economic realms. Moreover, critics often argued that ICDPs ran counter to the need to base biodiversity conservation on rigorous biological science (Bray and Anderson 2005).

A recent exchange in Worldwatch among anthropologist Mac Chapin, representatives of major international conservation and development institutions, and indigenous, NGO and academic stakeholders (Chapin 2004) suggests that establishing and maintaining appropriate relationships among highly diverse stakeholders in conservation and development remains a key issue. Although attempts to promote greater community involvement have often had limited success, cases exist of grassroots initiatives in which communitylevel stakeholders have claimed pivotal roles in local resource management decisions and have assured that their voices are considered in policy decisions affecting their livelihoods. Examining such cases can provide insight for developing strategies that reconcile conservation and development agendas with the needs and preferences of local people living in close proximity to forests.

That conservation and community livelihood objectives must be reconciled as part of any forest conservation strategy is becoming increasingly clear. Some 60 million highly forest-dependent indigenous people live in the rainforests of Latin America, West Africa and South East Asia. Another 400-500 million people are directly dependent on forest resources for their livelihoods (White and Martin 2002). Moreover, today as much as one-quarter of the forests in developing countries are community owned or managed (White and Martin 2002; Molnar 2003). According to Molnar (2003), in 2002 communities owned or administered 377 million ha or $11 \%$ of the 3.6 billion ha of global forest. If developed countries in which government-owned forests predominate are excluded, the community share of the global forest increases to $25 \%$. These figures represent a doubling over the last 15 years, and some observers predict they are likely to double again in the next 15 years.

Several questions have arisen in the context of growing community involvement in forest management: Under what conditions do local people collectively defend their interests by forming social movements to maintain their access to forests, and how do they develop into forest steward communities contributing to environmental governance? What is the role of the state in producing formative conditions for social movements or in impeding them, and how do the relations between state entities and grassroots groups affect forest governance? What types of or approaches to assistance best support grassroots social movements and encourage the emergence of forest stewardship communities? How can external support engender sustainable local capacity building in pursuit of positive social and environmental outcomes? How can partnerships be developed that recognize the unique capabilities ${ }^{1}$ and potentials that each set of international and local actors bring to forest stewardship?

This occasional paper examines four cases of grassroots forestry organizations which have emerged as significant social movements representing communities living in and around protected areas.

- In Guatemala, the Association of Forest Communities of the Petén (ACOFOP) leads a movement of diverse community-based organizations that have won rights to manage forest concessions in the multiple-use zones of the Maya Biosphere Reserve.

- In Acre, Brazil, the struggle of rubber tappers to secure property rights to maintain their forest livelihoods has allowed rural communities to gain recognition for their traditional landholdings. Residents have remained active participants collaborating

\footnotetext{
1 In this paper and its companion paper (Taylor et al. 2007), we refer to community 'capability', following the distinction that Morgan draws between 'capacity' (existing skills and behaviour patterns within an organization) and 'capability' (what an organization can do) (Bonis-Charancle et al. 2007). Our thanks to Carol Colfer for pointing this out.
} 
with progressive governmental agencies to develop alternative policies supportive of forest peoples in the region.

- In the Siuna region of Nicaragua, the Farmerto-Farmer Programme ( $\mathrm{PCaC}$ ) has developed into a movement which enlists farmers near the Bosawas Biosphere Reserve in efforts to slow the advance of the agricultural frontier, to develop sustainable agroforestry and cattle-raising, and to contribute to the ecological sustainability of Bosawas via peasant biological corridors.

- In the Brazilian state of Amazonas, communities faced with the inclusion of their traditional territories within the Mamirauá Sustainable Development Reserve (RDSM) have been able to organize and negotiate a more equitable plan that allows them to remain and continue traditional extraction activities under sustainable management guidelines negotiated collaboratively.

In these four areas, regional context studies analyzed the nature and development of the four grassroots forestry movements. In the Central American communities, the project facilitated participatory reflective studies by local people examining the communities' experience with forestry and technical assistance (Taylor et al. 2007). Finally, project findings were evaluated at an international exchange meeting in the Petén, Guatemala, involving community representatives from participating sites, technicians and external researchers.

Too often, conservation vs. development, and external expert vs. community control, have been framed as 'either/or' propositions. This project $^{2}$ aims to help reframe the debate to find common ground for more effective collaboration among major stakeholders in forest conservation and development by identifying instances where broad-based organizations have contributed to positive outcomes by becoming networks of forest steward communities. We believe that a balance between conservation and development is possible in many situations, and that collaboration with grassroots organizations is not only a potentially successful strategy but is necessary to achieve equitable and sustainable outcomes.

This document is organized into three sections subsequent to this introduction. The next section will focus broadly on the trajectory of the selected grassroots movement cases comparing and contrasting their experiences and outcomes. It will draw largely, but not exclusively, on the context studies generated as part of this project (Cuellar and Kandel 2005; Gomez and Mendez 2005; StoneJovicich et al. 2007a, b). The fourth section will identify some of the lessons learned from these experiences as well as common tendencies that could guide future technical assistance efforts in support of grassroots forestry movements. The final section provides conclusions from this work.

2. The Grassroots Assistance Project was sponsored jointly by the Center for International Forestry Research (CIFOR), the Central American Indigenous and Peasant Coordinator of Communal Agroforestry (ACICAFOC) and the Amazon Institute for People and the Environment (IMAZON). The Central American team was led by Rubén Pasos and Nelda Sanchez, sociologists and community development specialists associated with $\mathrm{ACICAFOC}$, and included researchers from the Salvadoran research NGO, PRISMA. The Brazil team was led by Paulo Amaral, senior environmental researcher at IMAZON, with Samantha Stone-Jovicich taking the lead on the Brazilian context studies. Staff from Colorado State University and the University of Florida provided technical and advisory support. The project was carried out in collaboration with these grassroots organizations to better understand their experience defending their environmental, economic and political interests, to distinguish factors that contributed to their success, including technical assistance and development programmes, and to examine the influence of these groups on forest conservation. A key objective was to identify assistance approaches that could be adapted to support these groups and similar movements in other places. 


\section{The Development of Forest-Based Grassroots Movements and Models of External Technical Support}

The Grassroots Assistance project's regional context studies analyzed the historical roots of the four grassroots organizations and the emergence of forest stewardship communities that build on the organizations' networks of horizontal and vertical alliances. The studies examined the impact of these groups on forest governance and their contribution to conservation and development. They also explored the role of external assistance and how different models have facilitated the growth and increased the capability of these organizations.

Each case study illustrates innovative experiences with the protection of natural and cultural resources via pursuit of conservation and community livelihood strategies. All of these grassroots forestry organizations emerged in response to uncertain tenure, weak governance resulting in high levels of environmental and/or social conflict, and little official mediation due to weak or unsympathetic state institutions. These were conditions which some Central American partners have characterized as 'ingovernability'. Each grassroots movement has received significant state and international technical assistance, but a critical common thread was early assistance that emphasized strengthening local institutions, establishing the basis for networking, and facilitating reflection on common problems. The communities' collective responses pressured governments to recognize their rights to and control over their landscape and gave them important influences on the direction of conservation and development initiatives in high conservation value forests. Now, with basic access to resources largely achieved, the forest-based community movements and their organizations struggle to adapt to the changing needs of their membership while maintaining and extending external political support for their role in resource management. These pressing challenges call for new approaches to external assistance that can provide needed skills and resources while enhancing local capacities for effective management.

\subsection{Communities and Forest Concessions in the Petén, Guatemala: The Case of ACOFOP}

In Guatemala the Association of Forest Communities of the Petén (ACOFOP) has shown how by demanding and gaining control over forest resources organized communities can stabilize and maintain forests in volatile frontier regions. This grassroots forest organization, whose members administer a large proportion of the best managed forests of the Petén, emerged because of the direct threat to communities' wellbeing posed by the initial design of the Maya Biosphere Reserve (MBR). While representing a strong social movement, the communities' interest in forest management also dovetailed with larger political openings created by the 1996 Peace Accords and international reluctance to give industry the predominate role. In this context, they managed to establish an effective indigenous organizational voice capable of promoting their interests in legal and political arenas.

The Petén is located in northern Guatemala, bordering with Mexico to the northeast and with Belize on the southeast (See Figure 1. The Petén and Siuna, Central America). The lowland tropical forests of the Petén are recognized worldwide for their wealth of biological diversity, and ancient Mayan archaeological sites. The MBR, established in 1990 as part of the United Nations' Man and the Biosphere Programme, aims to conserve the region's archaeological and biological treasures, safeguard its diverse ecosystems, and promote 


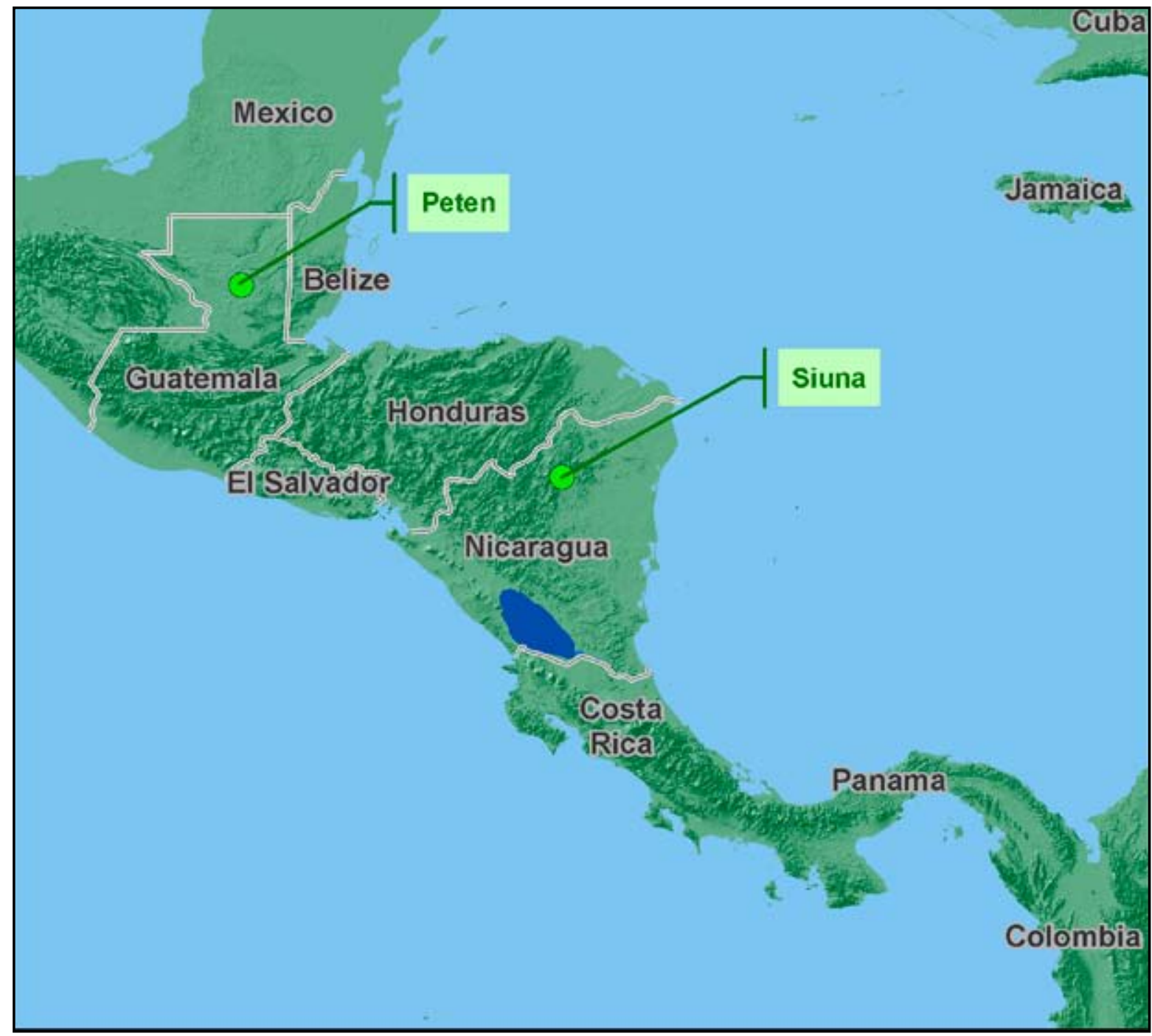

Figure 1. The Petén and Siuna, Central America

opportunities for sustainable use of natural and cultural resources (Gómez and Méndez 2005; CONAP 1996; UNESCO 1996). Although ACOFOP is a successful manifestation of this type of integrated approach to conservation and development, it continues to struggle to maintain its position and control over tropical forests held in concession.

For many years Guatemala's most geographically and politically isolated region, the Petén has been shaped by competition among different stakeholders to control its wealth of natural resources. The Petén's communities are quite diverse in historical origin, ethnic composition and productive activity. Throughout the twentieth century the region was settled by consecutive waves of official and spontaneous settlements, so today the Petén's 367000 inhabitants are mostly migrants from other departments. Extractivist communities were established as early as the 1920s as harvest camps for chicle gum (Manilkara spp.), and the ornamental greenery xate (Chamaerdorea elegans, C. oblongata and $C$. ernesti-augustii), and have diverse economic strategies centring on non-timber forest activities. Beginning in the 1960s, statesponsored colonization policies used the Petén as a safety valve for social conflicts generated by demands for land in Guatemala's interior provinces. Campesino (peasant) communities were established during this time by indigenous and ladino (mestizo, or mixed) settlers to pursue swidden agriculture and even largescale ranching. Other stakeholders arrived 
to extract petroleum, precious minerals and timber. These new arrivals greatly accelerated forest conversion.

During the latter period of the counterinsurgency war in Guatemala (1994-6) and the period of transition into the postwar period, refugees forced from the highlands into exile in Mexico were given the option to return to the Petén, where they encountered a mixture of extractivist communities and other recent migrant families settled on public forest lands. Oral histories tell of encounters filled with tension as some 'newly arrived' communities and ex-guerrilla leaders proposed parcelling the land for agricultural purposes, while forest-dwelling communities defended the forest and their forest-based livelihoods. Over the years, as migration to, passage through and plans for the Petén increased, it became clear that the Petén had evolved from being the vast 'empty' hinterland of Guatemala to become the grounds for competing interests and political instability. This context of demographic, cultural and economic diversity was exacerbated by growing pressures for land and problems such as contraband and illegal narcotics activities.

The Petén has also been shaped by a weak state presence and policies that are often ambiguous or contradictory. Between 1959 and 1987, the FYDEP (Promotion and Development Company of the Petén) was the only government agency with a significant presence in the region. FYDEP aimed to incorporate the Petén into the economic life of Guatemala through policies promoting resource extraction and colonization (Schwartzman et al. 2000; Gómez and Méndez 2005). In 1989, the National Commission for Protected Areas (Consejo Nacional de Areas Protegidas - CONAP) replaced FYDEP and was charged with administering what would become the MBR. The appearance of CONAP signalled the movement of an environmental agenda to the forefront of state policy in the Petén.

The MBR's design and implementation have been profoundly shaped by the Petén's high levels of conflict and frequent absence of formal state control, the aforementioned 'ingovernability'. The MBR's original territorial scheme, which encompassed 2112940 ha, included a Nucleus Zone under strict conservation rules, a Multiple Use Zone (MUZ) representing about $50 \%$ of the MBR in which various sustainable non-timber activities could be carried out, and a Buffer Zone in which land and resource use was to be stabilized to relieve pressure on the MBR. Within this framework, CONAP's mandate was to halt illegal logging, the advance of the agricultural and cattle frontier, the sacking of archaeological sites and illegal traffic in drugs, fauna and migrant workers (Nittler and Tschinkel 2005).

Unfortunately, as has often occurred elsewhere with protected areas and forest reserves (McShane 2003), the MBR's original policies for use of the MUZ and buffer zones did not take into adequate account the complexity of the region's pre-existing diverse population and natural resource-use patterns. On the contrary, bans and other restrictions on usage were originally imposed on populations both within the reserve and in its surrounding buffer zones. The MBR's initial restrictive policies triggered serious conflicts with the local population. These conflicts were complicated by a new wave of internal migration in the 1990 s caused by the economic crisis and the return of displaced refugees (Elías et al. 1997 in Gómez and Méndez 2005). New waves of agarradas (land seizing) were established de facto by squatters. As competing interest groups attempted to guarantee their access to land, resources and passageways through the forest, the establishment of a conservation 'regime', which was premised on social exclusion from the forest, met with unexpected resistance. Violence, including burning vehicles and guard posts and kidnappings, was unleashed against CONAP staff (Cuellar in Gómez and Méndez 2005).

By the late 1990s it had become clear that CONAP was experiencing great difficulty in managing the contradictions in state policy and social conflict arising from the MBR. Significantly, the terms of the Peace Accords that had put an end to three decades of civil war in Guatemala included provisions for distribution of land to ex-combatants and returned refugees. In numerous cases, these land grants overlapped with areas of forest formally under the protection of the MBR. The government's complex political 
commitments worked at cross-purposes with its own environmental agenda and complicated the MBR's administration. In this context a combination of factors opened the way for greater community participation in the MBR and for the emergence of the grassroots forest organization, ACOFOP. The MBR was a key piece of a larger international strategy of protected areas and reserves in Central America. Influential international stakeholders including donor governments and international conservation organizations such as Conservation International, The Nature Conservancy, and other institutions wished to mitigate conflict surrounding the MBR's administration and address the government's inability to exercise control by promoting broader community involvement in the management of the reserve.

The granting of forest concessions around the MBR was seen as a promising option for mitigating social conflict and facilitating more effective management of the reserve. An intense debate ensued over whether to grant forest-management concessions to the timber industry or to communities. Forest industrial interests lobbied hard to gain the concessions, supported by allies in the government. In 1995 community-based groups established an organization to pursue forest-management rights that would become ACOFOP, with the objective of improving 'the standard and quality of life of the Petén's forest communities, through sustainable management of the forest's resources' (ACOFOP 2005). International conservation groups, for their part, opposed industrial concessions, and while they saw migrant farmers as 'predators' on the forest they argued that peteneros (long-term residents with traditions of chicle and xate extraction) had a 'forest culture' compatible with sustainable forest management (Gómez and Méndez 2005). The controversy was ultimately resolved, at least temporarily, by the granting of 25-year forest-management concessions to six local communities within the MUZ, six communities bordering the MUZ and two local forest industries (Nittler and Tschinkel 2005; see Figure 2. Community Concessions in the Petén). ACOFOP was key in the communities' winning the concessions. Gómez and Méndez

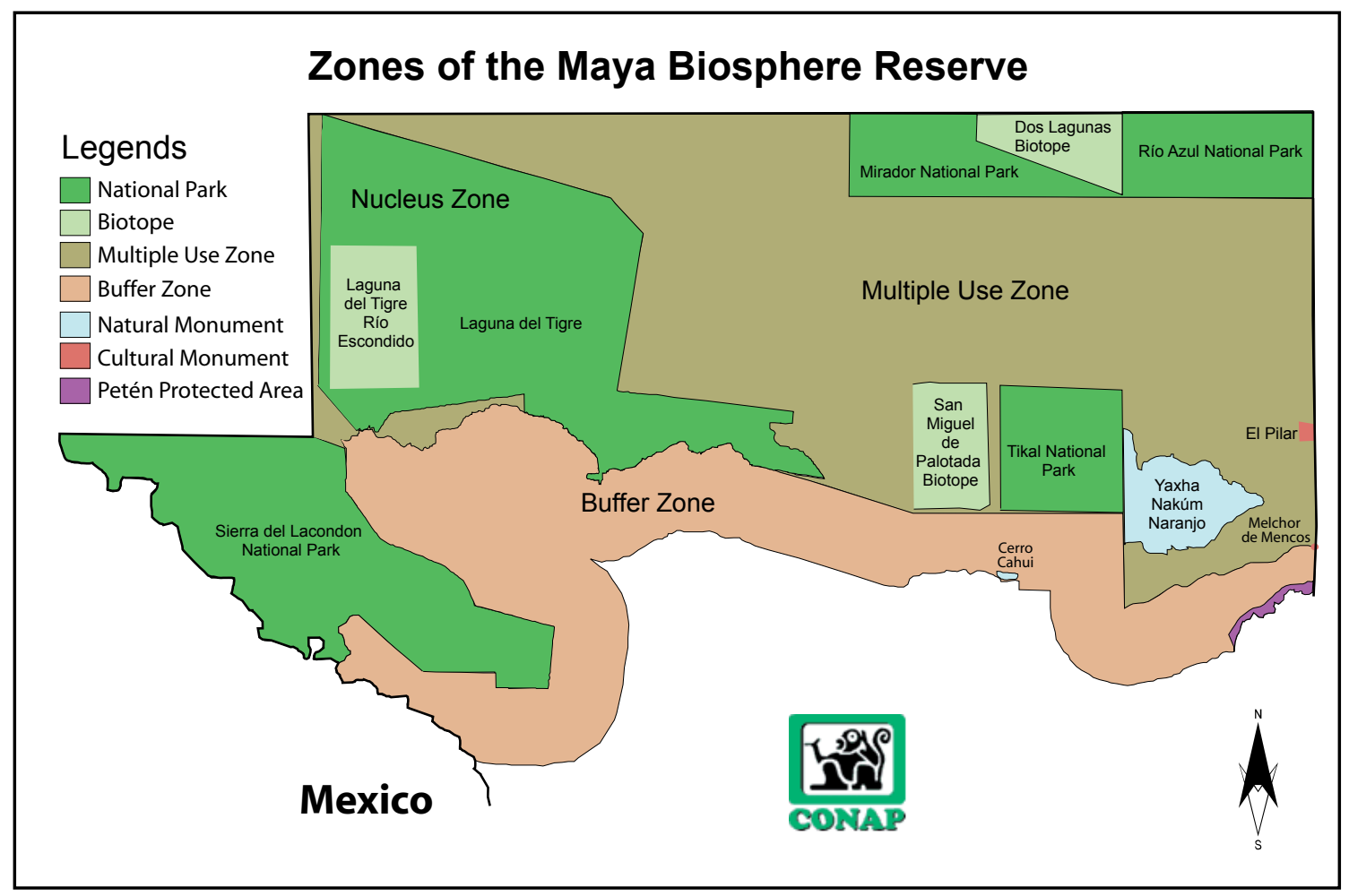

Figure 2. Community Concessions in the Petén (based on PRISMA 2005) 
(2005), point out, however, that international support for granting community concessions signalled more an opposition to industrial concessions than a strong belief in local communities' capacities.

During the definition of the MBR international donor and conservation institutions played a crucial role in pushing conservation and development dialogue and in promoting the inclusion of community-level actors. Principal donors in recent years have included the United States Agency for International Development (USAID), the World Bank, the German Kreditanstalt für Wiederaufbau (KFW), the British Department for International Development (DFID), and the Ford Foundation. USAID alone invested an estimated \$40 million in the Petén between 1990 and 2004 in support of CONAP and protected area management, including direct support to the communities with forest concessions. USAID also promoted the close involvement of international conservation organizations such as Conservation International, The Nature Conservancy, and CARE (Gómez and Méndez 2005).

The community concession contracts originally required communities to sign exclusive technical assistance contracts with local non-governmental organizations (NGOs), themselves linked with the larger international conservation organizations. These international NGOs and their national counterparts played a positive role in many ways. They helped communities satisfy legal and bureaucratic requirements to gain forest concession rights. They carried out socio-economic and technical planning, and provided valuable technical assistance and training in forest management, tourism and marketing. '...These donations generated significant technical knowledge and capacities related to forest management, which were appropriated by community members as well as by government institutions and NGOs' (Gómez and Méndez 2005). Moreover, community members learned and appropriated ecological perspectives and were pushed to organize more effectively. This 'official' model of technical assistance has had important strengths. It is highly effective at mobilizing large-scale financial resources and in contributing technical knowledge and skills.
It has recruited the participation of important institutions in technical areas of ecology and natural resource management (Gómez and Méndez 2005).

However, the relationships between communities and the NGOs, according to many community members and observers, were ultimately characterized by paternalism and dependency. ACOFOP and its associated communities and organizations complained that the NGOs' methodology did not allow communitiestodevelop theirowncapabilitiesfor integrated forest management, administration and business. '...the relationship between communities and the NGOs that accompanied them was imbalanced from the start, since the NGOs managed and administered the funds without promoting community institutional strengthening and self-management' (Gómez and Méndez 2005). In numerous cases, NGOs providing assistance to community concessions operated much as technical service 'buffets' selling services, an organizational orientation with little vested interest in turning over increasing responsibilities to communities. Pasos (2006) remarks that the NGOs were designed from the top down and tended to evolve into project implementers, reducing the community to the role of 'beneficiary'. Their staff tended to focus on satisfying donor requirements and, as they were hired by the NGO rather than selected by the community, they ended up working for the NGO in the community rather than working for the community.

From the perspective of ACOFOP and its associated communities and associations, with few exceptions, the external investment in assistance was rarely oriented 'toward the strengthening and training of the communities or ACOFOP in financial and administrative management' (Gómez and Méndez 2005). Traditional models of technical assistance assumed that communities were made up of inexpert people, with little capacity to participate actively in management (Pasos 2006). In many cases, as the NGOs were born from or engendered by the larger international conservation organizations, the staff were not familiar with development, much less with community forestry, but rather with approaches more akin to conservation (Cortave personal 
communication). The model allowed NGOs to end up taking the place of communities in making decisions, competing with community administrative councils, and limiting access to key information. In numerous cases, the NGOs 'assumed a protagonist role in the process and instead of being accompanists or facilitators, they turned into service providing firms', which also controlled commercialization, effectively becoming new intermediaries (Gómez and Méndez 2005).

ACOFOP's leaders learned that CONAP had divided up the region and, together with USAID, had 'assigned' different NGOs responsibility for each region without community consultation, an arrangement common in the history of forest services or extension in other countries. After numerous accounts of disrespect and excessive 'gate keeping' by NGO personnel, the Petén community concessions countered this arrangement. With pressure from ACOFOP, including international internet-based campaigns and, crucially, support from USAID, this obligatory NGO model was ended in 2001. USAID began directly strengthening the community concessions in 2002, emphasizing reduction of subsidies, strengthening of business management and reduction of assistance agencies (Gómez and Méndez 2005). Communities gained greater freedom to seek technical assistance adequate for their needs, within a framework of compliance with the technical requirements of the concessions' contracts. Several NGOs continue today to provide technical assistance to the concessions, though on terms more acceptable to the communities. ACOFOP's member communities have now crafted a protocol which lays out the parameters of a respectful, negotiated set of principles and procedures for 'gaining access' to the communities as service providers (Cortave personal communication). A number of NGOs have been converted into private service providers, which can be acceptable to communities, given adequate transparency in roles and responsibilities. Today, several of ACOFOP's associated members obtain forestry technical guidance, including support for forest certification procedures and timber commercialization, from a community-owned forest services firm, FORESCOM (Gómez and Méndez 2005).
In the Petén over the last 10 years, experience with an alternative model of technical 'accompaniment' has contributed valuable resources for development of the community concessions and of ACOFOP. Several key international institutions and foundations, including the Ford Foundation, Project Agricultural Frontier, the CIR (Iniciativa Cristiana Romero), the Inter-Ecclesiastic Organization for Cooperative and Development, the German Service for Social Cooperation, and Helvetas of Switzerland, have explicitly directed support to community concessions in ways which promote the development of the communities' organizational and political capacities. These institutions have differed from traditional technical assistance by channelling their investment directly to the incipient community institutions. The Ford Foundation, for example, targeted its investment of \$US 470000 between 1999 and 2004 directly to the institutional development and capacity strengthening of ACOFOP.

These institutions' financial contributions have been more modest than those of official assistance, but their focus has led them to assume a role of 'accompanist' of a social process rather than a provider of assistance towards a set of largely externally defined project objectives. The authors use the term 'accompanist' to highlight the level of partnership between communities and external institutions promoted by alternative assistance models, in contrast to assistance that creates dependency relationships.

In this accompaniment process, external support institutions and communities 'travel together generating ideas and identifying challenges to the consolidation of community forest management' (Gómez and Méndez 2005). This 'pro-community' model of technical assistance aims to promote both the organizational and political capabilities of communities and their grassroots organizations. It does this by promoting: a) direct funding to the community institutions, b) a focus on helping improve the abilities of the community organization itself in information gathering, self-diagnosis of member needs, expansion of their institutional presence and communications capacity, c) methodological 
training in shared learning, d) development of social networks at national and international levels, and e) provision of inputs and resources such as access to external information, linking with relevant processes and events worldwide, as well as complementary financial support to other 'allied' organizations that can provide crucial technical inputs. In fact, horizontal networking has been key for ACOFOP's members. For example, early in the concession experience they sought advice on community-based forestry and forest certification from community members and forestry technicians from the highly successful Plan Piloto Forestal ejidos of Quintana Roo, Mexico. The pro-community model ' . . .implies a more flexible model of cooperation, more horizontal, and closer to populations and their processes. Not being tied to project logic, this type of cooperation maintains a supportive orientation to a long term process' (Gómez and Méndez 2005). Significantly, despite the fact that its primary role is not to provide technical support to community concession organizations, ACOFOP has developed in its own right into a key indigenous accompanist to the community concession process in Guatemala, a common role for secondary-level organizations comprised of community organizations.

By 2005, ACOFOP had 22 member communities and organizations representing some 14000 individuals in 30 communities. ACOFOP's members manage what, at $500000 \mathrm{ha}$, is termed the largest expanse of forest under community management in the world, nearly $70 \%$ of which has been certified by the Forest Stewardship Council as sustainably managed (ACOFOP 2005; Nittler and Tschinkel 2005).

On balance, the community concessions have produced highly positive impacts on conservation and economic wellbeing in the communities. Recent satellite and on-site observational data show that natural and cultural resource areas under community concessions have suffered far less degradation from fires, illegal settlements, theft and vandalism than those in the MBR's nucleus, parks and protected areas, and buffer zones. 'Despite constant challenges, the evidence indicates that forest management in the Petén is functioning, from the perspective of resource management, community income and conservation of biodiversity' (Nittler and Tschinkel 2005; also see Radachowsky 2004; Roney et al. undated). The community forest concessions generate an annual value of \$US 5 million in wood products and \$2-3 million in non-timber forest products (NTFPs). Members of community firms receive an average of \$US 1120 for wood-product extraction and processing, and on the whole in 2003 generated over 50000 person days of work with a value of nearly \$US 360000 (Nittler and Tschinkel 2005). ACOFOP observes, moreover, that its members' forest concessions in 2003 generated over \$US 424000 in taxes (ACOFOP 2004).

Today, ACOFOP and its members are seeking to move beyond commercial timber extraction, to develop a more integrated management approach including the harvest of NTFPs such as xate (jade palm) and chicle (natural gum), environmental services, community-based ecotourism and cultural site protection. They hope that this more integrated approach will help consolidate the community concessions for the future, responding to conservationist concerns about timber exploitation and opening up new opportunities for both concession members and non-members (Taylor 2007).

The community concessions of the Petén face significant obstacles today, especially those operations with the weakest organizations and the least commercially valuable forests (Nittler and Tschinkel 2005). They also face scepticism and outright opposition from industry and some NGOs (Gómez and Méndez 2005; see Tropico Verde 2005). CONAP has come to strongly support community involvement in forest management, yet it is not the only government institution with influence in the Petén and in the MBR. Guatemala's tourism and cultural ministries, for example, have overlapping jurisdictions which shape resource management in the region.

The right of communities to participate in forest management continues to be an ongoing struggle in a context in which natural resource conservation and development are shaped by powerful external actors. Numerous times over the past 10 years, for example, the Guatemalan government has attempted to expand petroleum exploration and exploitation in areas under community forest concessions. 
According to community leaders, it is common for the army to be deployed to accompany petroleum technical missions. ACOFOP and local concession members have systematically opposed these endeavours and mobilized to bring national and even regional-level attention to this violation of their agreements and rights. In most cases, they have been successful in thwarting further action on behalf of the authorities and the petroleum companies (Cortave personal communication).

In 2003, however, a new proposal to protect the Mirador Basin in the northern Petén emerged which posed threats to the gains that communities had achieved in natural resource management. The US-based Foundation for Anthropological Research and Environmental Studies and the Global Heritage Fund proposed a new NTFP initiative to protect approximately $2000 \mathrm{~km}^{2}$ of an area including the MiradorRio Azul National Park, the Naachatún-Dos Lagunas Biotope and six community-forest concessions. The plan's proponents argued that illegal hunting, logging and archaeological theft threaten the area's biodiversity and its ancient Mayan cultural treasures. The proposal would have halted the forest management and livelihood strategies in concessionaire communities. It proposed integrating community members into private 'sustainable eco-tourism initiatives' with monetary compensation for halting timber harvesting.

The plan had substantial international and national political and financial support and was supported by the Office of the Guatemalan President at that time. Nevertheless, the Cuenca Mirador project appeared to bypass CONAP's jurisdiction and to contradict MBRrelated policies and laws by proposing to eliminate significant portions of existing community and industrial concessions. The project was challenged in court by ACOFOP on behalf of the community concessions and their allies (including some industrial groups). They argued that the Mirador Basin Project was a 'top-down' initiative which emerged without consultation with affected communities (Gómez and Méndez 2005). The project's plan to develop tourism also contained significant contradictions which might actually increase pressures on the integrity of the MBR (ACOFOP 2005). The project's legality was overturned by Guatemala's Supreme Court in mid 2005 (ACOFOP 2005). The future of the Mirador Basin and its relationship to community management of the MUZ continues to be unclear. A new proposal emerged in late 2005 for UNESCO to declare the region a global Cultural Heritage site (Cortave personal communication). In 2007, discussions were under way in the Petén of new projects to develop the tourism potential of Mirador. An Inter-American Development Bank (IDB)-supported Sustainable Development Project for the Petén was awaiting Guatemalan congressional approval. However, ACOFOP and its associated communities had succeeded in gaining more formal participation in negotiations related to these and other proposals affecting the community concessions (Cortave personal communication; Córdova personal communication).

\subsection{The Struggle for Property Rights and Forest Livelihoods in Acre, Brazil}

Acre is a small, remote state located at the far western edge of the Brazilian Amazon, on the border with Peru and Bolivia (see Figure 3. Acre and Mamirauá, Brazil). It is a state probably best known as the birthplace of the rubber tapper movement, the movement's most famous leader, Chico Mendes, and for the struggle to gain recognition of property rights through the creation of extractive reserves (Reserva Extrativista - RESEX) and extractive settlement projects (PAEs). Both the first PAE in Brazil, São Luis do Remanso, established in 1987, and the first RESEX, Alto Juruá, established in 1990, are located in Acre (MDA et al. 2001; IBAMA 2005). Two of the reserves best known nationally and internationally are located in the state: the Chico Mendes RESEX, encompassing 970570 ha, and the 24 898-ha Chico Mendes PAE (otherwise known as Cachoeira). Since the 1990 s, $48 \%$ of the state of Acre has been placed within conservation units, which include RESEX and PAEs (Governo do Estado do Acre - SEIAM 2005). As a result of these conservation efforts and the state's relative isolation, Acre still retains approximately $90 \%$ of its original forest cover. The rubber tapper movement in Acre played a pivotal role in the shift in forest policy in the Brazilian Amazon, and it is remarkable that a network that began as a movement of impoverished forest people 


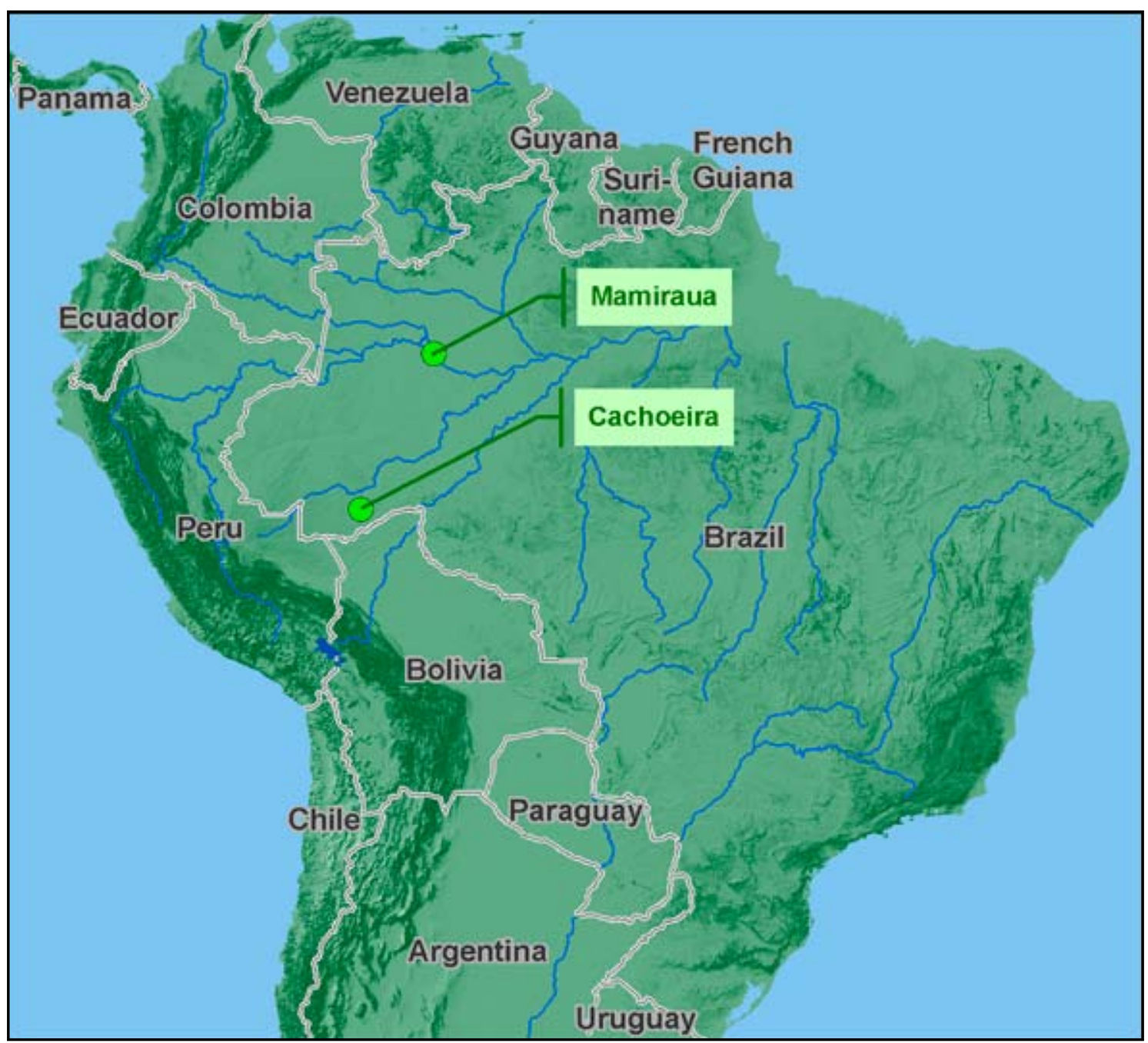

Figure 3: Acre and Mamirauá, Brazil

defending their livelihoods could successfully form alliances with key international actors and influence policy at the regional scale.

Acre traces its historical roots to the rubber boom of the late nineteenth and early twentieth centuries. During the rubber boom, Acre's forests were divided into large estates owned by rubber barons (seringalistas), each with a workforce of indebted rural labourers. The workforce was composed of migrants who originally left Brazil's impoverished northeastern states searching for work tapping rubber, but once the rubber trade collapsed during the first decades of the twentieth century the hold over this rural labour force relaxed and many families became semi-autonomous producers, adding subsistence agriculture to their work extracting rubber and Brazil nuts (Bertholletia excelsa). Descendants of these migrants, known as seringueiros or rubber tappers, continue to maintain livelihoods that are highly dependent on forest resources.

After the collapse of the rubber economy, Acre, like much of the Amazon region, occupied a marginal position in Brazil's economy. During the 1960 s, Brazil's military government viewed the Amazon as an empty region that needed to be integrated into the national economy, made more productive and populated (Mahar 1989). Massive governmental development initiatives provided incentives for the entrance of large-scale enterprises and established huge colonization projects to resettle displaced and landless families from other regions (see also Schmink and Wood 1987, 1992; Revkin 1990; Binswanger 1991; Souza 2002). In the early 1970s, the regional development bank, BASA (Banco da Amazônia - Bank of the Amazon), 
discontinued credit lines for rubber extraction, forcing many of the remaining seringalistas into bankruptcy.

While the seringalistas were being forced out of business, the state government began encouraging investors from southern Brazil to invest in Acre, primarily in large-scale agricultural and cattle projects. As a result, landholdings passed to new owners and began to be further concentrated. From 1970 to 1975, $38 \%$ of Acre was sold to only 284 investors (Cavalcanti 1994). At the same time, the state refused to recognize the traditional land rights of the rubber tappers occupying the forests. Instead, when investors began clearing forest the government offered to relocate these families to colonization projects elsewhere in the state. However, promised support for colonization projects often proved inadequate. Many families were pulled from their existing social support networks in the relocation process. Colonization plots were too small for traditional extractive activities, and most relocated families lacked capital to invest in agriculture. These problems were compounded by a mixture of poverty and disease that caused extreme hardship and forced families to abandon homesteads and move instead to peri-urban shanty towns (Bakx 1988). As news spread of the difficulties faced by families pushed into colonization projects, resistance to official development policy grew in the countryside.

Being dispersed and isolated in the forest did not provide rubber tappers with ideal conditions for organizing collective action. However, a series of efforts by outsiders helped establish the basic conditions for rubber tappers to begin organizing to defend their rights. One important institution was the Catholic Diocese of Acre and Purus, which was strongly influenced by liberation theology for the defence of human rights. With the arrival of Bishop Dom Moacir Grechi in 1973, the church began emphasizing the formation of ecclesiastical base communities, religious organizations at the community level that also provided space for political discussion (Souza 2002). In 1976, Bishop Moacir denounced the expulsion of rubber tappers and instructed rural priests and nuns to begin informing rubber tappers of their land rights. Parallel to the actions of the
Catholic Church, labour organizations began working in the region using the base created by the religious organizations to form rural labour unions. The first such union was formed in the rural town of Brasiléia in 1975, and by 1980 there were eight union groups in Acre (Sandri 2003). These groups were united under the banner of the Confederation of Agricultural Workers (Confederação dos Trabalhadores na Agricultura - CONTAG), which opened an office in Rio Branco, Acre, in 1975.

Catholic lay volunteers and union organizers from CONTAG focused on establishing local organizations, explaining legal rights and discussing the collective interests of isolated forest families. As the movement grew in strength, local unions made explicit efforts to raise consciousness and build consensus around the rubber tappers' collective interests. Linking rural wellbeing to the forest became a key component of an emerging rubber tapper identity (Grzybowski 1989). In 1981, a series of NGOs including CEDOP (Centro de Documentação e Pesquisa da Amazônia - which later became the CTA: Centro de Trabalhadores da Amazônia), CESE (Coordenadoria Ecumênica de Serviço) and CEDI (Centro Ecumênico de Documentação e Informação) along with the anthropologist Mary Allegretti initiated a rural education programme called the Projeto Seringueiro (Cordeiro and Castelar 1988). Inspired by Brazilian educator Paulo Freire (see Freire 1970), by drawing examples from the region's forest context for teaching materials the project made education more accessible but also implicitly validated the rubber tapper identity.

One of the innovative ways in which the rubber tapper movement developed to resist expulsions was through the use of a nonviolent collective action called an 'empate'. In an empate, families from surrounding communities would occupy areas slated for clearing by ranchers. With the targeted areas filled with men, women and children, it was impossible for work crews to cut trees or enter with bulldozers. In 1976, the Brasiléia rural union organized the first empate in a property called Seringal Carmen, but the Xapuri rural union, formed in 1977, quickly became the most active in the organization of empates (Sandri 2003). Between 1976 and 1988 
there were a total of 45 empates, of which 15 successfully halted forest clearing (Assies 1997). While unable to halt deforestation completely, this non-violent activism drew national and international attention to the rubber tapper cause.

The efforts at forming community-level organizations began to coalesce into wider networks as communities united in response to threats to their livelihoods. In 1985, the first national meeting of Amazon rubber tappers was held in the national capital, Brasília. During the meeting, the National Rubber Tappers Council (Conselho Nacional dos Seringueiros, CNS) was formed; this was the first national organization capable of representing the interests of rubber tappers and other forest workers in Amazonia effectively (Schmink and Wood 1992). The CNS was led by the charismatic president of Xapuri's rural union, Chico Mendes.

The CNS rapidly began to garner greater attention through its collective actions and strategic alliances with international environmental organizations, notably the Environmental Defense Fund and the National Wildlife Federation (Schmink and Wood 1992). As this happened, the rubber tappers gained momentum in their struggle to force the government to recognize the property rights of traditional peoples living in the Amazon. In 1987, after Chico Mendes was invited to Washington by the Environmental Defense Fund, mounting pressure forced the IDB to halt funding for paving the BR-364 highway between Porto Velho and Rio Branco, the capital of Acre. Resumption of the project was contingent on the enforcement of the social and environmental protection programmes (an IDB programme known as the Programme for the Protection of the Environment and Indigenous Peoples - PMACl) by Brazil's federal government. Eventually the federal government gave in to the CNS's principal demand for the recognition of traditional property rights by creating RESEX and PAEs. Both RESEX and PAEs recognized the existing land rights of rubber tapper families, allowing them to maintain their traditional livelihoods.

Once property rights had become more secure, assistance programmes shifted towards projects intended to help rubber tappers improve their wellbeing and use of forest resources. A good example of this trend was the formation of the Brazil nut cooperative CAEX (Cooperativa Agro-extrativista de Xapuri) in 1988. The cooperative was initiated by Xapuri rural union with assistance from several national and international NGOs including Cultural Survival, theFord Foundation, Inter-American Foundation and WWF (Assies 1997). In 1990 CAEX received financial and technical assistance to build the Chico Mendes Brazil Nut Processing Plant to offer members a better price by selling nuts directly to international markets. However, CAEX was unable to operate the plant at full capacity and because it was difficult to compete against lower-priced nuts from Bolivia the plant nearly stopped operating after a couple of years (Assies 1997). In 1992, CAEX shifted its strategy to decentralize production by introducing mini and micro factories in communities around Xapuri. This was an attempt to lower production costs, to directly increase incomes of rubber tapper families, and to provide an incentive to stay in the forest, but this change did not resolve the principal problem - which was competition from lower-priced nuts from Bolivia (Assies 1997). Although the decentralization plan provided a new source of income for women and young people in the rural areas, it was short lived (Campbell 1996) in part due to problems with quality control. The establishment of the main plant and the smaller factories was CAEX's principal strategy for increasing the economic return that rubber tapper families received from NTFPs. However, given the limited success of efforts to generate increased income by processing Brazil nuts, the need for forest-based production alternatives for rubber tapper families remained.

The rubber tapper movement continued to expand alliances and to gain political influence. The assassination in 1988 of Chico Mendes deprived the movement of its charismatic head and an innovative leader but it also increased long-term international and national attention on the issues and mobilized the rubber tappers. The strength of the movement was crucial in supporting efforts by the rubber tappers' allies to gradually take control of local and state governments after Brazil's military government stepped aside and democracy returned to the country in 1986. As the rubber tappers' allies occupied seats of power they 
began channelling increased assistance and projects to rural communities, while the state government actively participated in defining an alternative development vision in the 1990s and continues to do so. In Acre, the rubber tapper movement became closely aligned with the Brazilian Workers' Party (Portuguese acronym: PT) and what became known as the 'popular front', a coalition composed mostly of small leftist parties (Fernandes 1999). In 1992, a leader from the CNS was elected mayor of the Xapuri municipality (and the movement also gained control of the important Rio Branco municipality). In 1998, the PT candidate was elected governor. This government prioritized the maintenance of the state's forests and began implementing policies and strategies to promote sustainable development in partnership with the state's traditional forest people (Witoshynsky 2002; Duarte 2003; Kainer et al. 2003). Shifting dramatically from the policies of earlier governments, the 'Forest Government', as it became known, announced the goal of halting deforestation at $18 \%$ of the state's surface area and placing $25 \%$ of the state's forests (approximately 4 million ha) under sustainable forest management (Caminoto 2000). Community forest management was to play a key role in the government's plan for reaching this goal (MMA/Governo do Acre 1999; Witoshynsky 2002).

The success of the rubber tapper movement and its allies has pushed the pro-forest, procommunity agenda to the forefront of regional debates. Sustainable, multiuse forestry has become a principal tenet of dominant political discourse in the region. There are disputes over emphasis on NTFPs or timber, but there is broad general agreement that forest management should be a priority for community development in Amazonia. The rubber tapper movement is not solely responsible for all of this change, but the movement played a key role in propelling current decision makers to office. The movement was a crucial force in changing or at least broadening development discourse and action to consider pro-forest approaches to the Amazon.

While the new property rights sheltered rubber tapper families from loss of livelihoods, they were still under pressure to adapt and change.
Profits from rubber, which had been the mainstay of rural livelihoods in Acre, declined after removal of national subsidies in 1986 and price supports in 1992. Rubber was replaced by Brazil nuts, but prices have historically fluctuated, indicating the continued risks from boom-bust extractive cycles.

When the 'Forest Government' increased support, services and the construction of infrastructure for forest communities, a priority programme was the promotion of sustainable forest management, particularly timber management at all scales including the community level. The government created an agency charged with supporting forest development programmes, the Secretaria Executiva de Florestas e Extractivismo (SEFE), and reorganized the state's extension service, the Secretaria de Assistência Técnica $e$ Extensão Agroforestal (SEATER) to better meet the needs of forest populations by shifting from an exclusive emphasis on agriculture to one that includes forestry topics in extension programmes.

Efforts to expand and diversify rubber tapper livelihoods began to focus on alternatives such as timber management. The Xapuri municipal government, controlled by a former CNS leader, wanted to develop a small woodprocessing industry to generate economic activity in the region. However, it was not easy to find communities willing to participate. The introduction of timber management into PAEs or RESEX communities was perceived by some as a contradiction of the rubber tapper movement's basic principles to protect the forest. Cachoeira, due to its strong political ties to leaders in Xapuri, agreed to participate, and 10 families initiated work on a trial basis in 1999.

The results produced by introducing timber managementhavebeenmixed. Theparticipating Cachoeira families quickly mastered the management techniques, however some aspects of the production process were beyond the communities' control. The Cachoeira project revealed persistent obstacles with the administrative bureaucracy of the Instituto Brasileiro do Meio Ambiente e dos Recursos Naturais Renováveis (Brazilian Institute for Environment and Renewable Natural Resources - IBAMA), and limited market access of small- 
scale producers, problems that have required considerable external assistance (StoneJovicich et al. 2007b). As a result, even after the initial phase Cachoeira's families have had to rely on continued technical assistance from the state and NGOs, and there has been limited success in expanding the model beyond the original 10 families. Also, the timber management project has primarily benefited a small segment of the population with the negative consequence of increased internal divisions within the community. As a result, families in less accessible sections of the community have become disgruntled and have even formed a parallel community association (Stone-Jovicich et al. 2007b). This raises the question of whether these types of initiatives will have long-term benefits once support from the state ends. Despite these challenges, since 2000 the state government has expanded its technical forestry assistance to approximately 26 other communities living in RESEX, PAEs and colonization projects interested in sustainably harvesting timber (Governo do Acre - SEIAM 2005). In 2005, the state, with the support of CNS, formed the first cooperative in the Amazon of community-level timber producers (Cooperativa dos Produtores Florestais Comunitários - Cooperfloresta) in an effort to help communities produce sawn lumber and market their timber in larger volumes.

The majority of RESEX and PAEs in Acre were established in regions marked by conflicts between rubber tappers and ranchers and, more recently, small-scale agricultural producers (colonos). While the creation of these federally-owned conservation areas has helped reduce land disputes by giving rubber tappers secure usufruct rights to remain on the land and to continue to extract renewable forest products at ecologically sustainable levels, challenges remain. The RESEX and PAE designations gave residents communal title but left the internal division and distribution of resources to their customary practices. The state, through IBAMA, has maintained oversight of forests, mandating the percentage of properties that can be legally deforested for agriculture or other uses, and regulating forest management and logging activities. Strict environmental regulations plus the slow and sometimes contradictory bureaucracy of
IBAMA have presented obstacles to efforts to develop innovative forest management systems. Furthermore, because of limited success in improving the livelihood conditions in the forest, rubber tappers families, facing continued poverty and hardship, have increasingly turned to cattle ranching and/or the expansion of agricultural plots.

\subsection{Farmer-to-Farmer Collaboration to Slow Forest Degradation in Siuna, Nicaragua}

In the Siuna region of northeastern Nicaragua, a local Farmer-to-Farmer Programme ( $\mathrm{PCaC}$ ) has developed into a rural network strengthening environmental governance around the Bosawas Biosphere Reserve (see Figure 1. The Petén and Siuna, Central America). The region holds ecosystems of rich biodiversity, and the Bosawas Reserve, together with three neighbouring protected areas of Honduras (Río Patuca National Park, Tawhaka Anthropological Reserve and Río Plátano Biosphere Reserve), forms the heart of the Mesoamerican Biological Corridor and represents the largest protected area complex of tropical montane moist forest north of the Amazon basin (Cuellar and Kandel 2005; UNESCO 2005). The development of PCaCSiuna illustrates how the exchange of shared experience has allowed rural producers to respond to the more deleterious consequences of frontier expansion and ameliorate negative conservation trends.

Siuna has a history of geographic, political and economic isolation as an extractive enclave with relatively little state presence. The result has been conflict and weak governance, with diverse social groups competing to extract the wealth of its mineral, forest product and agriculturala and ranching potential. Many of the earliest inhabitants of Siuna arrived to work in the region's mines, on its banana plantations and in its timber industries or simply sought land for small-scale agriculture and animal husbandry. Siuna served as an escape valve for pressure for landless people elsewhere in Nicaragua where land was more concentrated in the hands of large terrateniente landowners and as state policies promoted official and spontaneous colonization (Cuellar and Kandel 2005). 
In the 1980s, during Nicaragua's Civil War, Siuna was an important source of support for antigovernment rebels and the site of protracted conflicts in the countryside between Contra and Sandinista forces. After the war, Siuna's population increased significantly, as displaced peoples returned and as the government distributed land to ex-combatants. In the early 1990s, nearly 500000 ha of land were distributed to ex-combatants, with $66 \%$ of this land being given to ex-Contras (Cuellar and Kandel 2005). Even after the Nicaraguan Peace Accords of 1987 that ended the armed conflict between Sandinista government troops and Contra fighters, Siuna continued to experience a high level of conflict as armed movements sought reparation for civil war losses, indigenous and mestizo groups and national and international extraction industry disputed resource access and tenure, and illegal loggers, drug traffickers and others struggled for control of the area (Kaimowitz 2002; Cuellar and Kandel 2005). 'The region was a no man's land. Only the army, armed groups and PCaC moved about freely' (Cuellar and Kandel 2005).

The 1987 establishment of the RAAN and RAAS (Autonomous Regions of the North and South Atlantic, respectively) reflected acknowledgement by the state that to improve relations with indigenous and other local groups the more isolated Atlantic regions required special autonomy. Nevertheless, specific arrangements to devolve state power to the regions were slow to emerge, as the question of autonomy has been shaped by conflicts within national parties and relatively undeveloped regional parties (Cuellar and Kandel 2005).

Furthermore, in Siuna state policies have often pursued ambiguous or contradictory objectives of development and conservation. For example, despite having promoted colonization in the region Nicaragua participated in the move among Central American governments towards policies promoting environmental conservation. Nicaragua supported the development of a Mesoamerican Biological Corridor, declaring Bosawas a National Natural Resource Reserve in 1991; the reserve gained recognition as a UNESCO Biosphere Reserve in 1997. At approximately 2 million ha, Bosawas represents $14 \%$ of the territory of Nicaragua. Its Nucleus Zone includes almost 800000 ha; its Buffer Zone represents another 1.3 million ha (Cuellar and Kandel 2005).

The Bosawas reserve was established with strong international bilateral and donor support, but with little consultation or participation from indigenous and mestizo groups already living in the territory. The international and national institutions helping set up Bosawas did not at first fully appreciate the potential role that communities in the Buffer Zone could play in support of the reserve's integrity. An estimated 25000 inhabitants of Miskito and Mayangna indigenous communities live in the Bosawas Nucleus Zone. More than 200000 persons, mostly mestizo campesinos, are estimated to live within its Buffer Zone. The Buffer Zone and the community actors within it were mostly overlooked, as most attention focused on primary forests with little attention paid to the important role that buffer zones play in maintaining the stability of ecosystems (Cuellar and Kandel 2005). While attempting to conserve huge expanses of territory, government efforts ran counter to the strategies of the region's existing residents and previously resettled populations. The managers of Bosawas initially sought major restrictions on access to and use of forest resources, although because of the relative haste in which it had been established specific regulations had not originally been put in place. The Bosawas Management Plan limited explicit recognition of communities to those within the Nucleus Zone, which were almost all indigenous. The creation of Bosawas itself sparked a resurgence of indigenous claims for land and the formal, legal demarcation of land boundaries (Cuellar and Kandal 2005). This provoked conflicts that have largely pitted indigenous and mestizo campesinos against each other in the competition to define territorial boundaries and use rights, in large part because of the dichotomy maintained between Nucleus and Buffer Zones (Cuellar and Kandel 2005).

Since the reserve was created, Bosawas has faced significant and growing pressure from outside its boundaries as the agricultural frontier has been pushed closer by farmers and ranchers (Cuellar and Kandel 2005). 
Nicaragua's land tenure system as manifest in Siuna has been at the centre of the problem of resource ingovernability along the agricultural frontier. Because of the region's history as a colonization zone and extractive enclave, occupation continues to be the principal method for acquiring land rights. Colonists lay claim to land by felling trees, cultivating crops and erecting structures. Possession rights are legally defensible after one year. Property rights can be acquired with a clear land-grant document after 10 years. Otherwise, property rights for 'improved land' can be acquired after 30 years. While relatively few inhabitants possess clear, legal title to the lands they occupy, paradoxically a thriving but volatile land market exists in which land improvements and existing use rights are traded. Colonists typically claim and 'improve' land, sell it and move on to new sites. The state's rural credit systems reinforce this system of 'property rights through improvements' (Cuellar and Kandel 2005). The result is a dynamic which encourages land-use change, expanding the agricultural frontier which threatens encroachment on Bosawas boundaries. However, as these dynamics progressed and the frontier in Siuna began to close, small-scale rural producers began looking for alternatives.

In 1987, as Nicaragua's official institutions were privileging state agricultural and ranching firms and the cooperative movement, one of the few concrete projects supporting small producers was the introduction of the Farmer-to-Farmer Programme known by its Spanish acronym PCaC (Programa Campesino a Campesino). PCaC was introduced by the National Union of Farmers and Ranchers (Unión Nacional de Agricultores y Ganaderos - UNAG), the Sandinista-controlled rural union (Cuellar and Kandal 2005). First developed in Guerrero, Mexico, PCaC was part of a growing grassroots movement throughout Central America of farmer-based campesino experimentation with farmers teaching farmers in a self-reliant approach aimed at building social and human capital. (See Holt-Jiménez [2006] for a comprehensive discussion of the history of $\mathrm{PCaC}$, from its origins in Guerrero, Mexico, to its evolution into a region-wide grassroots movement). PCaC's participants shared innovations with each other in exchange meetings emphasizing horizontal learning and adaptation, then returned home to further disseminate useful experiences. After several years of operating at the margins of both governmental and union promoted programmes, the UNAG helped expand the $\mathrm{PCaC}$ programme as a means for reflecting on the reasons for the Contra uprising, its support in the country's rural hinterlands, and as a vehicle for reconciliation of opposing sides. PCaC was seen as offering a chance for dialogue and reconciliation among individual small-scale farmers who had been caught up in the Civil War struggle and had not been well served by the government's policies favouring cooperatives.

UNAG introduced PCaC to Siuna in 1993. Oxfam-UK provided the first external support to PCaC through UNAG by funding farmer exchanges and workshops in Siuna's mining areas. Members of the Rosa Grande community travelled from Siuna to Boaco in central Nicaragua and returned with knowledge of the bean cover crop frijol abono (Mucuna pruriens) which makes possible greater weed control and enhanced soil fertility on farmers' lands. The use of frijol abono reduces the need under traditional small-farmer swidden cultivation systems to periodically clear and burn new areas. By the following year, the cover crop experiment had spread to five communities in Siuna.

Oxfam financed a project from 1995 to 1997 to expand experimentation with the bean cover crop sown in combination with maize and to organize exchange visits to share results among farmers. After two years, 25 PCaC-affiliated promoters and 76 producers were using and promoting the cover crop to transform their traditional agricultural practices. Oxfam support eventually made possible expansion to eight more communities, and additional exchanges. Another important source of assistance was the Central American Indigenous and Peasant Coordinator of Communal Agroforestry (ACICAFOC), which regularly organized regional exchanges in which $\mathrm{PCaC}$ participants were able to link with international social networks and to exchange knowledge and information with other farmers in the region. As a result, with ACICAFOC support PCaC-Siuna members promoted more than 1000 ha of corredores biológicos campesinos (peasant biological corridors) 
to connect their communities with Bosawas (PCaC-Siuna, undated a).

PCaC's experience with technical assistance has been shaped largely by its relationship with its parent institution, UNAG. Shortly after its introduction, PCaC-Siuna was widely viewed as a stronger and more influential organization in the countryside than its parent institution, UNAG. This situation led to internal conflicts, particularly with relation to the channelling of external resources via UNAG to PCaC. The internal tensions were partially rooted in fundamental organizational differences between UNAG and PCaC. While UNAG has a formal, top-down, hierarchically structured organization, $\mathrm{PCaC}$ - despite being an assistance programme - took on innovative characteristics better conceptualized as those of a social movement or collective action network. PCaCSiuna's affiliates are not part of a formal PCaC organizational hierarchy. The strong ties of PCaC-Siuna's network of volunteer promoters are based on PCaC's success and credibility. Communities' and promoters' ties to $\mathrm{PCaC}$ have more to do with the shared interests of a social movement rather than positions within a formal framework.

When the national organization attempted to exercise direct control over the disposition of the funds and, consequently, PCaC's activities, $\mathrm{PCaC}$-Siuna members resisted and through local elections managed to place their members in decisionmaking positions in UNAG, thus assuring local influence in decisions. PCaCSiuna continues to be formally affiliated with UNAG, but after a difficult period of tension and negotiation has achieved a greater degree of autonomy from its parent institution.

Today, PCaC-Siuna directly organizes 120 communities and has indirect influence in another 300 communities through its network of almost 500 volunteer promoters in the region. $\mathrm{PCaC}$ has assumed a key role of technical accompanist to its member communities' social processes. $\mathrm{PCaC}$ provides the framework for the work of the network of promoters in the communities, organizes technical backstopping for the experimentation and dissemination of sustainable production techniques, and arranges exchange events among farmers. The success of PCaC-Siuna has drawn the attention of donors and projects. As a result, $\mathrm{PCaC}$ has also assumed an important role as interlocutor between external state institutions and international donors with interest in supporting producers in the region.

$\mathrm{PCaC}$ continues to work to resolve the tension between its need to seek resources and technical assistance in support of its members' aspirations for more stable and sustainable livelihoods, and the very characteristics of horizontality and process orientation which have won it such widespread support and influence in the region. PCaC's leaders and members have begun to realize that much external technical and financial assistance arrives as formal projects that encourage the development of a rigid, top-down organization like that of UNAG. Official objectives, timelines and financial accountability requirements of projects necessarily lend themselves to, and even require, formal institutional structures and traditional organizational hierarchies of technical experts and community beneficiaries. While such organizational changes often produce benefits such as increased efficiency and transparency, formal project imperatives often run counter to the more horizontal, process-oriented principles of a farmer movement which pursues strong, yet informal social networks of experimentation and exchange.

The contradictions that official projects pose for $\mathrm{PCaC}$ as a movement, for example, were dramatized when $\mathrm{PCaC}$ found itself responsible for enforcing loan agreements and collecting debts incurred by members participating in a farmer loan project, a relationship that threatened to undermine its capacity to sustain its social networks in the countryside (Cuellar and Kandel 2005). In another example, the World Bank recently supported an NTFP project to harvest and process essential oils in $\mathrm{PCaC}$ communities in Siuna. This support led to the formation of a new PCaC-affiliated cooperative with 55 members, COOPESIUNA (Cuellar and Kandel 2005). The surge in support also offered challenges as it undercut the movement's basic organizational logic. For example, in interviews carried out by the authors during March 2004, cooperative members expressed concern about top-down decision making 
and lack of information about the essential oils project, which was driven by outside consultants. As Pasos (2001) points out, such situations are common in many traditional projects: "it has been the people who end up accompanying the [outsider's] project in execution of its activities' rather than being supported by it.

$\mathrm{PCaC}$ has developed into an important movement promoting sustainable agriculture and ranching in the region of Siuna. Though it is first and foremost a loosely knit association of farmers now stabilized on a forest frontier, $\mathrm{PCaC}$ has become a major source of support for forest conservation. $\mathrm{PCaC}$ has contributed significantly to slowing the advance of the agricultural frontier in Siuna. The vast majority of farmers in PCaC's area of influence have decreased their dependence on burning and have begun replenishing their soils by planting cover crops and practising other sustainable techniques. Internal $\mathrm{PCaC}$ reports (PCaC-Siuna undated $b$ ) state that an estimated 3000 farmers in 80 communities use frijol abono on more than 5000 ha. Some 300 families have seen their production operations stabilized, with planned and diversified farms. By increasing family food security, PCaC's participants have greatly reduced the impetus for new land clearing. Their actions have protected 2500 ha of forest from felling over the previous eight years and 15000 ha of degraded forest have been set aside for restoration in those 80 communities. The group has planted approximately 25000 Pimienta Pimenta doica trees and an additional 10000 trees of other species in agroforestry systems. The expansion of pasture for cattle continues to be a threat to the forest, even after farmers have stabilized their agricultural plots and homes. Given their focus on the conservation impacts of their agricultural work, PCaC's members have begun to experiment with more intensive pasture management techniques in the forest area.

Cuellar and Kandel (2005) state that a new social campesino actor is being promoted by $\mathrm{PCaC}$ in Siuna. Contradicting the predominant discourse which labels mestizo farmers as pioneers on the agricultural frontier and environmental predators, the emerging figure of the forest steward community shows that it is possible to conserve natural resources via productive proposals emerging from the communities. One of PCaC's challenges is to establish a new and more explicit role in environmental governance related to the Bosawas reserve.

Of $11 \mathrm{PCaC}$ initiatives in Nicaragua, it is in Siuna where the movement has had greatest success, in terms of leadership and membership growth, and in terms of technological impact on smallscale farming and animal production (Cuellar and Kandel 2005). Pasos (2001) argues that $\mathrm{PCaC}$, however, is more than a collection of methodological tools or agricultural techniques; rather, it has become 'the most important productive movement in the Nicaraguan countryside, through which small farmers and ranchers confront the ongoing crisis in rural life, and it is generating new proposals for development of farms and communities' (cited in Cuellar and Kandel 2005). In a strategic sense, the principal attraction of $\mathrm{PCaC}$ in Siuna lies in its methodology of horizontal dialogue, communication, and empowerment.

\subsection{Collaborative Community Conservation and Sustainable Forest Management in Mamirauá, Brazil}

The Mamirauá Sustainable Development Reserve represents an innovative case of collaboration between conservation scientists and communities living in and depending on the forests in the Amazon flood plains that fall within the reserve. The Mamirauá Sustainable Development Reserve (Reserva de Desenvolvimento Sustentavel Mamirauá - RDSM) is located in the Brazilian state of Amazonas, encompassing 1124000 ha at the confluence of two of the Amazon's larger tributaries, the Solimões and Japurá Rivers (See Figure 3). Mamirauá is the largest reserve dedicated to the conservation of várzea flooded forest in the Amazon, a floodplain landscape of forests interspersed with canals and lakes marked by dramatic shifts in water levels due to seasonal flooding (Queiroz 2001). In part because of its unique várzea ecosystem, the reserve is recognized worldwide for its high biodiversity; it was originally created in 1990 as an ecological station to protect the endangered primate Uacari-branco Cacajao calvus calvus endemic to these forests. 
However, the site is also noteworthy as the origin of an important innovation in Brazilian conservation policy. In 1996, Mamirauá was transformed from a conservation area to a Sustainable Development Reserve, recognizing the rights of local communities living inside and on the borders of the reserve to remain and to use its natural resources. This exceptional turn of events occurred when organized rural communities in Mamirauá and conservation proponents agreed that collaboration could be mutually beneficial.

The region around the Mamirauá reserve has a long history of intensive extractive activities, in large part because of its location at the confluence of the extensive Solimões and Japurá Rivers. In the late nineteenth century, the rubber boom attracted migrants from the northeast of Brazil who came to work as rubber tappers. With the collapse of the rubber economy at the beginning of the twentieth century, rubber tappers and itinerant merchants abandoned the forests and rivers and founded the first settlements that comprise presentday Mamirauá (Alencar 2002). The collapse of world rubber prices created an economic vacuum that was filled with new products to sustain the debt-peonage system established in the region during the rubber boom. Logging increased in response to demand for wood for steam ships (Alencar 2002). Starting in the 1930s, commercial fishing operations moved into the region from as far away as Colombia and Peru. Loggers started to arrive from the nearby Brazilian cities of Manaus, Itacoatiara and Tefé. These activities predominated until the creation of the Mamirauá reserve.

The current population of the RDSM descended from families that settled during the rubber boom, although the population had declined by the 1960s (Inoue 2003). In 2001 there were 98 settlements and 137 isolated households in the reserve for a total of 5829 inhabitants (Moura 2001 cited in Inoue 2003). Most of these settlements are located along the natural levees of the Solimões and Japurá Rivers and other canals running through the reserve. Because the rivers create a shifting landscape the communities frequently need to change location; the average length of occupation of any one locale is estimated at about 40 years (IDSM 2000; Alencar 2002).
The fluctuating water levels create a unique mixture of aquatic and boreal ecosystems, and families living in this shifting landscape have adapted their livelihoods to match. Fishing in the myriad lakes, canals and river channels allows families to meet their subsistence needs and provides a source of cash income. The forests produce important NTFPs such as fruits and fauna, and timber provides a major source of cash income for some families. The shifting beaches and levees provide soils that allow swidden agriculture, but only briefly during the dry season.

Historically the settlements along these rivers lacked strong organizational institutions. It was only in the 1970s that the Catholic Church began organizing communities and implementing a programme called the Movement for Grassroots Education (Movimento de Educação de Base - MEB). The programme promoted a sense of communal responsibility among residents in the dispersed settlements and began training leaders. The organizational development of the communities took another step in 1979 when a Catholic missionary from the Tefé Diocese known as 'Brother Falco' began a programme called the Community Lake Preservation Movement (Movimento de Preservação dos Lagos Comunitários - MPL). This programme was an attempt to facilitate coordination among residents to better manage aquatic resources that were vital to local subsistence and income. The communities' resource base had long been under pressure from commercial fishers, particularly those using boats with improved technology, such as nylon nets (Alencar 2002). Management promoted by the MPL consisted of classifying lakes into three use categories: lakes for reproduction, lakes for subsistence and lakes for commercialization. The programme created an expanded role for MEB leaders and strengthened the incipient political organizational structures of the communities. It also initiated a process by which communities began making collective decisions about resource management and were introduced to the idea of 'conservation', which played an important role in their eventual acceptance of the reserve.

The incipient community organizations were put to a test in the mid 1980s as a proposal was launched to create a conservation area encompassing the várzea forests and 
lakes at the juncture of the Solimões and Japurá Rivers. A leader in this conservation movement was the biologist José Márcio Ayres, who in 1983 had begun doctoral research on the endangered Uacari-branco found in the forests around Lake Mamirauá. In 1985, Ayres led a group that proposed that the Secretary of Environment from the State of Amazonas (Secretaria de Meio Ambiente do Estado de Amazonas - SEMA) turn the area into an 'ecological station' covering 260 000 ha to protect the primate. In 1990 the State Government of Amazonas created the Mamirauá Ecological Station, which covered 1124000 ha. Technically the creation of the ecological station would impose severe restrictions on resource use and access, and it would no longer be legal for residents to occupy the reserve. When the conservation proponents began to visit residents to discuss management issues and encountered hostility and distrust from community members, they realized that an alternative to the ecological station was necessary. At the time, the communities had not participated in the process and were largely unaware of changes that were being discussed. One reason for this was that the state did not attempt to enforce the provisions requiring the exclusion of resident families, and the conservationists did not push what they saw as an unrealistic and unjust position. There did seem to be some common ground between the conservationists and the residents as some community members recognized a decrease in excessive fishing and hunting behaviour because the ecological station had restricted access to the region by outsiders (Inoue 2003). The conservation proponents were able to build on this and the local desire to protect a diminishing resource base.

The period from 1991 through 1995 was dedicated to negotiations with the state government to create a new category of reserve, one which would permit local communities in Mamirauá to remain and to use the natural resources sustainably, and the development of a management plan for the area that became the reserve. In 1992 the researchers involved with the proposal formed the non-governmental organization (NGO) Sociedade Civil Mamirauá (Mamirauá Civil Society - SCM) to administer the project and facilitate the development of the management plan. An important focus of the assistance given by the SCM project team was to facilitate the participation of the communities in the reserve's management. The SCM team lacked the power to remove people from the conservation area and therefore realized that they depended on cooperation from families living in and around the reserve to make the initiative viable. With that in mind the project team embarked on an effort to develop a more collaborative approach that would involve communities in the process of defining management rules.

The SCM encouraged participation in management discussions by using the community organizations created by the Church's MEB programme as a framework to guide local inclusion. They promoted the formation of community-level associations organized around specific productive activities important to each community, for example fisheries management, timber management, crafts or agriculture, giving residents a voice in and platform for discussions of local management issues related to their livelihoods (IDSM 2001). The SCM requested that each community elect two representatives to participate in the discussions related to the management plan. In addition, the NGO grouped the communities into nine 'sectors' defined by the area of traditional extractive and agricultural activities, each with an elected coordinator (IDSM 2000; Alencar 2002). Each sector held periodic meetings involving community representatives and members of the NGO to discuss management norms and problems specific to the sector (IDSM-OS 2004). The multidisciplinary teams from the NGO worked at the sector and community levels mapping natural resources and customary use by communities as well as defining the limits of strict preservation areas in the sector. After mapping, they mediated negotiations between communities to determine access rights to forest and aquatic resources and assisted with the definition of norms for exploiting these resources. Starting in 1993, annual general assemblies of users of the reserve (Assembléias Gerais dos Usuários da Reserva) were organized to discuss the management plan and issues related to the reserve as a whole (IDSM-OS 2004). While representatives of other interest groups, 
governmental agencies and NGOs could participate, only the communities had the power to vote in the assembly.

Besides facilitating the definition of management norms, the NGO technicians began to provide assistance to communities to help them identify alternatives that would lower pressure on natural resources while ideally improving income. The Mamirauá timber management programme merits specific attention since this was a major area of technical assistance offered to the communities. Logging in the várzea forests had been an important economic activity for some families in Mamirauá for decades. When the SCM introduced the timber management project they did not try to radically change the traditional system in which flood waters transport logs rather than heavy machinery; instead they helped the communities organize the work, introduced techniques to make the activity more sustainable, helped the communities legalize the activity, and assisted them to negotiate better prices (IDSM 2002).

The roots of the Mamirauá community timber management originated in 1992 with a research project called the Mamirauá Timber Programme (Programa Madeira do Projeto Mamirauá) funded by the National Council for the Development of Science and Technology (Conselho Nacional de Desenvolvimento Cientifico e Tecnológico - CNPq), which studied biological and socioeconomic aspects of timber extraction in the reserve (IDSM 2000). From 1993 to 1995 , besides conducting inventories of forest species, the SCM monitored annual timber harvests, noting volumes, species and harvest locations as well as the residents and buyers involved, prices paid and forms of payment. The monitoring gave the SCM a fuller understanding of local practices, their impact on ecosystems and their role in local livelihoods. Using this information, the SCM facilitated discussions during the general assembly, where communities agreed that current practices were endangering some species and that there was a need to adopt other management practices (IDSM 2000). The timber management programme was finally initiated in 1996 (Stone-Jovicich et al. 2007a). In the first year there were no norms or set plans to structure the timber management programme. Instead, the extension team worked with the communities to build stronger relations with local community loggers, tried to identify doubts, expectations and difficulties, investigated levels of existing knowledge, and began introducing management concepts to the loggers (IDSM 2002). In 1997, timber management was incorporated in the Economic Alternatives Programme (Programa de Alternativas Econômicas) of the Mamirauá Institute of Sustainable Development (Instituto de Desenvolvimento Sustentável Mamirauá - IDSM), which included a variety of proposed activities to compensate residents for the restrictions on access and use established by the management plan (IDSM 2001). The MFC programme had the objective of increasing community income while at the same time conserving forest resources.

In 1998 the Government of Brazil issued Decreto 2788, which created simplified norms for community forestry management (known as PMFSimples), making it easier for small producers and communities to sell timber legally. Earlier the Brazilian Forestry Code (from 1965) had prohibited the harvest and commercialization of timber without a technical management plan; such plans were feasible only on a large scale and at substantial cost. In May 1999, IDSM organized a forum with federal and state environmental organizations - the Institute of Environmental Protection of the State of Amazonas (Instituto de Proteção Ambiental do Estado do Amazonas - IPAAM) and IBAMA - to discuss the legalization of timber extraction, via the simplified norms, in the RDSM (IDSM 2000). As a result, the IDSM adopted the goal of implementing community forest management in all nine sectors of the RSDM (IDSM 2000), focusing on areas where logging was a traditional practice, where there were high levels of illegal logging and where communities expressed interest. They used participatory methods to delineate community management areas and train community members in the new norms. By 2003 the total number of families participating in the MFC programme had increased to 236 families from 13 communities in 4 sectors (IDSM-OS 2004).

According to Pires (personal communication; see also Stone-Jovicich et al. 2007a), there 
are several reasons why the communities were dependent on external assistance to negotiate the bureaucratic process. First, the transaction costs are very high. The communities in Mamirauá lacked capital to cover the costs of forming official associations and many residents lack the required documentation. Even though the simplified norms reduced the paperwork, the forms required for approval of management plans still represented intimidating obstacles for locals, given the low levels of literacy found in the communities. To make matters worse, the forms were not adapted to conditions in várzea forests or the techniques used to log these forests, and the technocrats responsible for approving the management applications lacked understanding of conditions in Mamirauá. Finally, the approval process was very slow, taking on average five and a half months, complicating operational planning.

Initially neither Brazil's national government nor the state government of Amazonas actively participated in the process that created the collaborative arrangement between communities and conservationists in Mamirauá. However, over time governmental institutions provided the framework within which the RSDM evolved, and they gradually funnelled increasing financial assistance through the SCM to support the initiative. In the process the NGO responsible for the reserve gained a quasi-official status through agreements with the state government's institute, IPAAM, and the federal government's Ministry of Science and Technology (Ministério de Ciência $e$ Tecnologia - MCT) to take responsibility for administering the reserve and programmes intended for inhabitants. In 1994, the reserve began to receive significant financing from the $\mathrm{CNPq}$ to cover research, infrastructure and publications, at times reaching $40 \%$ of the total funding for the reserve (IDSM 2001). Substantial funding was also provided by the UK Overseas Development Administration (ODA), the Wildlife Conservation Society (WCS), WWF/UK and the European Union (SCM, CNPq/MCT, e IPAAM 1996).

In 1996, these efforts culminated in the creation by the state of Amazonas of the RDSM. Rather than being a strict conservation model, the RDSM offered a number of innovations. It would allow the population to continue to reside in the reserve and to play a role in defending its resources. The use of fauna and flora was permitted with a management plan based on scientific data but adaptable in response to new information or market change. The RSDM also authorized the implementation of programmes to improve local conditions, and established strategic agreements with government and NGOs to develop proposals for sustainable resource use.

In 1999 the researchers involved in the SCM formed a second organization, the IDSM. In the same year a presidential decree recognized the IDSM as an 'Organização Social' collaborating with the MCT. In 2000, the RDSM was incorporated into Brazil's National System of Conservation Units (Sistema Nacional de Unidades de Conservação). By 2002 an agreement with IPAAM passed responsibility for management of the reserve to the IDSM. The SCM continues as a network of interested researchers assisting IPAAM with the co-administration of the RDSM. The two organizations allow the researchers to tap into different sources of funding from the state and national government as well as funding from international donors. 


\section{Common patterns in the emergence of forest-based Social Movements}

Is it possible to generalize about how forestbased social movements develop by analyzing these four diverse cases? The selected cases are exceptional because they represent success by community groups in organizing grassroots movements that have ultimately secured greater control over forest resources. It is probably more common that forest people do not form grassroots organizations unless their forest-related livelihoods are threatened. What has made these selected groups' experiences different? The reasons for their success in organizing lie in complex historical processes shaped by a variety of factors, including the presence of charismatic leadership, the capacity to achieve consensus on the nature of external threats and the manner to respond, and the existence of political conditions making crucial alliances with external state and private actors possible.

Despite their significant differences, these social movements passed through similar stages. Each originated in a region with sporadic presence of state institutions and consequently weak governance mechanisms. As frontier change intensified competition for resources and as conflict and resource degradation increased, governments typically responded with conservation or development initiatives, often in the form of protected areas or reserves established with little or no consultation with local communities. These measures initially delegitimized, severely limited, or even eliminated community resource access, at least formally, but they also provided powerful catalysts for unity. Community-level stakeholders began to defend against external threats to their resource base, and with certain types of assistance collective movements began to coalesce. (See Colfer (2005) for a related discussion of the link between the success of Adaptive Collaborative Management (ACM) and high levels of natural resource-related conflict). After increased collective action and pressures for policy change, authorities eventually ceded greater control and access to communities and their grassroots movements. Significantly, although they won their battles through collective action these groups have struggled to maintain relevance to their members by capitalizing on their successes while adapting to new opportunities.

\subsection{Weak Governance on the Frontier and Threats to Livelihoods}

In all four regions studied, state institutions have historically been weak or absent. Remotely located at the margin of state influence, these regions provided a haven for indigenous or displaced populations. Rural peoples occupied these forest landscapes without formal title or officially recognized ownership rights. Where their arrival was not strongly contested by others, these groups managed to gain usufruct rights and develop livelihoods dependent on forest resources. However, their hold was precarious. State policies viewed forest regions as escape valves for conflicts, landlessness and unemployment. Eventually, increased migration, agricultural expansion and the quest for extractive resources brought frontier change to these regions, increasing competition for resources as well as conflicts between stakeholders. State policies viewed forested areas as unproductive and encouraged - explicitly or implicitly - their incorporation into national development agendas.

Policies intended to incorporate forest frontiers within national development agendas often failed to promote community involvement in resource management. On the contrary, they systematically encouraged investments that drove forest conversion to the detriment of rural people. Rural families struggled to preserve their resources while at the same 
time they faced increased pressure from and conflictswith competing stakeholders. Powerful interest groups, such as ranchers or loggers, benefited from the chaos and often laid claim to lands traditionally used by smallholders. Conflict and associated resource degradation raised the profile of these regions.

With time, as environmental degradation and social conflict became more apparent dominant policy directions shifted. Conservation agendas came to the forefront through policies shaping forest resource use and leading to the establishment of protected areas and reserves. In three of the cases reviewed here (the Petén, Siuna and Mamirauá), these conservation initiatives attempted, at least initially, to exclude local residents, including those already occupying newly designated conservation areas. However, states continued to support and implement conservation initiatives that excluded forest-dependent families, even in the face of national and international criticism of the policies (or lack of policies) that destroyed tropical forests or excluded the affected rural populations.

The imposition of national development agendas and conservation initiatives on what had been marginal forest frontiers jeopardized the livelihoods of multitudes of rural families and provided unambiguous threats to their wellbeing. In the cases examined here, especially those of the Petén and Acre, the introduction of change without adequate attention to local community interests generated significant social conflicts and sparked organized responses. Nevertheless, though state policies provided powerful catalysts for collective action, they were not fully responsible for the emergence of these groups.

\subsection{Community-level Stakeholders Respond with Collective Action}

The grassroots organizations reviewed here grew out of local initiatives and indigenous processes. Communities in these four cases worked hard to organize and pursue their interests collectively rather than struggle as individuals against powerful stakeholders. The clear recognition of a common shared threat to their livelihoods provided an important impetus for collective action.

The collective-action strategies adopted by the grassroots groups examined here operated at a number of levels. In some cases they adopted direct actions such as physically blocking deforestation, as happened in Acre, or by refusing to work with certain NGOs, as happened in the Petén. By acting together, these groups have managed to raise the public profile of their members, significantly neutralize economic and political disparity with competing stakeholders, and draw attention to their plight and the impacts on the forests they occupied. Their high profile actions and broad base of local support have made them attractive partners to external stakeholders. These groups have worked actively to present themselves as credible participants in natural resource management and have sought to form alliances with powerful external stakeholders. Initial success drew attention to their cause, helped them form alliances with national and international conservation groups, and eventually obligated the government to respond to their demands. These were all outcomes unlikely to be achieved by individuals or ineffectively organized groups.

An important factor in all four cases was that key actors, including state agencies, national and international donors and conservation groups, recognized that existing protected area management models were unlikely to achieve conservation goals effectively without better accommodation of community interests. In some cases, communities organized active resistance to prevailing resource management rules, triggering reflection on the part of protected area managers and their institutional supporters. In others, as in Mamirauá, conservation stakeholders realized early the need to incorporate genuine community involvement in resource management.

\subsection{Crucial Support from Two Types of External Assistance}

Each of the four groups studied here drew on external assistance that contributed in significant ways to the emergence and consolidation of broad-based community 
movements. The assistance received by the organizations has varied in both type and approach through what Gómez and Méndez (2005) called 'pro-community' and 'official' models of technical assistance. Rather than being mutually exclusive or competing models, these two have served different needs at different stages of communities' involvement in natural resource management.

The traditional or 'official' model of technical assistance has mobilized large-scale financial resources, technical knowledge and skills, and recruited important institutional participation in natural resource management. In Central America, examples included assistance from the United States Agency for International Development (USAID), the World Bank, Kreditanstalt für Wiederaufbau (KFW), the UK Department for International Development (DFID), international and national nongovernmental organizations (NGOs) and others. In Brazil, multiple federal ministries and agencies, such as the National Council for the Development of Science and Technology (Conselho Nacional de Desenvolvimento Cientifico e Tecnológico - CNPq) provided key assistance in Cachoeira and Mamirauá. This type of assistance was crucial in helping communities navigate the legal and bureaucratic requirements of formal forest management. In different cases, they have provided socio-economic and technical planning and provided important training.

A second, emerging 'pro-community' assistance model has focused more on the formation of community-based organizations, consciousness raising and building institutional capacity. This has involved the practice of collective reflection and analysis to promote group learning and adaptation and laid the groundwork for broader social and political networks by encouraging exchange and the sharing of experiences among groups in similar circumstances. This type of assistance has placed isolated frontier families in contact with others and provided a matrix through which individuals can share information and recognize common problems. Regular contacts between localized groups helped community members realize that others were confronting similar threats to their resource base. The resulting dialogue strengthened communities' capacity to define common agendas and collective strategies, resulting in more effective political negotiation capacities. (See this paper's companion study (Taylor et al. 2007) for a more detailed discussion of the organizational characteristics of this alternative model of technical assistance).

This approach to external support has attempted to create conditions in which rural communities can become active participants responding to their shared needs, generating processes of learning and ownership that local groups can sustain after external support disappears. Pro-community assistance has sought toavoid takingovertasks, responsibilities and roles that are already within local capacity, but rather to 'do only what local communities cannot do'. The farmer-to-farmer exchanges organized by Oxfam-UK with the Programa Campesino a Campesino ( $\mathrm{PCaC})$-Siuna and the community organization undertaken by Catholic activists in Acre are both examples of this type of assistance. When community organizations have developed sufficient institutional maturity, they have often sought greater responsibility for management and an effective role in negotiating and planning implementation, thereby developing a significant level of control over the process. The pro-community model has assisted community groups in reaching greater levels of organization and institutional stability, in more effectively representing and integrating their members' interests, and in negotiating a more equal footing with other stakeholders.

While pro-community approaches were very influential, they are not a panacea. Often local stakeholders need other assistance to learn the 'rules of the game' and the skills necessary to take advantage of new opportunities. The 'official' or traditional model of assistance has involved greater levels of funding and focused most specifically on technology and skills transfer. This type of assistance was a crucial support, for example, in the early years of the Association of Forest Communities of the Petén (ACOFOP)'s struggle to win forest management concessions for its member communities. It was also key in efforts by NGOs in Brazil to introduce sustainable timber management projects. As stated above, this type of technical assistance arrives in the 
form of formal projects requiring traditional organized hierarchies that often run contrary to the horizontal, process-oriented principles of social networks structuring grassroots movements. Even where projects avoid overtly paternalistic approaches that generate dependency, the demands of formal technical projects often push participants to respond to pre-set project objectives and conform to rigid planning frameworks. Nevertheless, in early stages of community involvement in resource management, traditional models of assistance have helped establish basic legal, organizational and technical foundations, particularly at larger scales.

\subsection{Forest Social Movements Face New Challenges in Adapting to Changing Contexts}

Once these grassroots movements succeeded in gaining more secure resource access, their organizations shifted focus to better support their members' changing needs. Their attention has turned to helping members take advantage of policy gains and improve livelihood conditions by exploring alternatives for expanding or diversifying forest production. This shift has taken varying forms of seeking project support to improve forest related income, identifying new production strategies, improving marketing capacity and developing greater and more complex involvement in resource management. For example, in Acre the rubber tapper movement and its allies have searched for ways to increase income from forest resources (a Brazil nut cooperative, decentralized nut processing, and the introduction of timber management). In Mamirauá the coordination of lake management and legalization of sustainable forest management have allowed residents to reduce uncontrolled resource use. In the Petén, ACOFOP's member community concessionaires are seeking to develop moreintegrated resource strategies that go beyond commercial timber to include organized management of non-timber forest products (NTFPs), tourism and cultural protection. In Siuna, $\mathrm{PCaC}$ has focused on green manure and agroforestry to slow deforestation on a closing frontier and seeks a more formal role in the management of protected areas in their region.
Consolidation of communities' significant success in natural resource management requires them to develop greater capacities to manage the complex politics of their resource base. For example, these grassroots organizations continually seek to balance conservation and livelihood goals. While conservation is an important component of their organizations' agendas, participating members expect their organizations to continue to generate concrete improvements in their livelihoods, often measured in terms of employment and income. At the same time, the external legitimacy of grassroots forestry organizations' management of forest resources greatly depends on the communities' ability to demonstrate that they are sustainably managing and conserving the resources. Though state support for community-based resource management has increased, grassroots community organizations must continually work to maintain and extend policy support for their role. Moreover, communities' credibility with conservationist stakeholders often requires countering competing stakeholder claims or criticisms, often based on overly narrow data and observations. Community groups need to develop their capacity to recount their own experiences more accurately and persuasively. This requires strengthening of local skills in the collection, analysis and presentation of data related to their forests and their activities in them (see Taylor et al. 2007).

State institutions have become more responsive when faced with collective pressure from grassroots movements and from international donors and NGOs seeking to reduce social conflict in threatened forests. The state recognized the property demands of rural families, sometimes creating novel mechanisms to respond to customary resource use such as community concessions, extractive reserves (RESEX), and sustainable development reserves. State interventions have provided legal frameworks, regulations, mediation and police authority that allow members of grassroots groups a more level playing field. In the Petén and Acre, for example, state agencies charged with protected area management have come to be strong supporters of the communities' role in sustainable forest management. 
However, in each case, as the state responds to multiple national and international interests, existing policy commitments to communitybased natural resource management are vulnerable. Grassroots groups in both regions struggle to maintain attention and keep their agenda under consideration by the state. In Central America the selected grassroots organizations still have a largely adversarial relationship with official agencies and must continue to bring pressure to bear to assure that their members' perspectives and interests are considered by policymakers. In the Petén, for example, the Mirador Basin Expansion Project, which directly threatened the community concession system, had strong political support at the highest levels of the Guatemalan state. In Siuna, PCaC still struggles to promote more significant consideration of its members' interests in the management of Bosawas. In both cases, the inability to assume a strong policy environment for communitybased resource management has spurred stronger group cohesion as well as expansion through the formation of secondary and tertiary organizations that broaden networks and strengthen collective bargaining power.

In Brazil, by contrast, the relationship between government and grassroots opposition has actually sometimes become blurred as the national government responds to collective demands by directly delegating responsibilities and funding to local organizations and NGOs. For example, the CNPq delegated significant responsibility and funding to the National Rubber Tappers' Council (Conselho Nacional dos Seringueiros - CNS) to co-manage the Chico Mendes Extractive Reserve. In the Amazon, because of vast spaces and relatively low population density, the government struggles to control and provide services to the dispersed rural population. Devolving responsibility to local organizations makes sense. Moreover, by subsuming groups within the system, the state manages to diffuse their power as opposition. The relationship between government and grassroots becomes even more complex as rural social movements take on greater political power. The gradual return of democracy in Brazil has meant that rural movements like that of the rubber tappers in Acre have succeeded in electing members and allies to local government. This has greatly enhanced their ability to channel resources and services to rural members. However, while programmes better match the needs of forestbased membership, state institutions still face political pressure to maintain the status quo and are not always capable of responding to innovative visions, resulting in traditional ineffective project implementation.

In all four cases, in both Central America and Brazil, grassroots community organizations face ongoing challenges to secure and extend state policy support for an authentic local role in resource management. While the focus of these grassroots organizations has shifted after initial resource access has been won, the need for effective political capacity has not abated. On the contrary, the political requirements created by an enhanced and diversified community role in resource management are arguably greater than those needed to win initial access. For example, in their pursuit of a greater role in integrated forest management, community concessionaires of the Petén face overlapping jurisdictions of ministries related to protected area management, petroleum exploration, tourism and cultural antiquities, in addition to similarly diverse and powerful organized international interests. As stated above, communities and their grassroots organizations clearly require strengthened capacities to study, analyze and present their own experiences in order to ensure that their interests are adequately represented in the highly competitive resource politics of their regions.

\subsection{Grassroots Movements, Forest Stewardship Communities and Conservation}

These four grassroots movements have gained control or influence over large tracts of forest on tropical frontiers. Gaining access to resource management has created greater stability, which allows local people to invest in the future of both their forests and their communities. Because their livelihoods depend on these forests, they have a great stake in maintaining the forests and investing labour and money to do so. Through these grassroots movements, forest steward communities are emerging. These communities hold a range of legal 
rights to manage forest resources and engage in productive activities, including extraction and processing of commercial timber, NTFP activities, agroforestry, sustainable agriculture and livestock production, and varying rights to participate directly in forest-related policies.

What are the emerging environmental and social impacts of forest steward communities on forest management? Reliable time series data on the conservation and development impacts of grassroots movements is still limited. Nevertheless, there is reason to expect significant positive impacts, particularly when compared to the alternative outcomes observed in neighbouring forest areas not controlled by such groups. These grassroots movements have contributed to increased stability in frontier areas by lowering conflict and improving property rights security; they have slowed processes driving degradation.

One of the most striking examples of conservation impacts and development can be seen in the Petén. Nittler and Tschinkel (2005) conclude that the community concessions are generating as much as \$US 5 million in timberrelated income and \$US 2-3 million from NTFPs. Dramatic satellite images show that in recent years much of the Maya Biosphere Reserve (MBR)'s buffer zone and neighbouring parks such as Laguna del Tigre suffer from seasonal forest fires. However, the zones covered by community concessions stand out for the lack of widespread fires (Wildlife Conservation Society et al. 2003, 2004). Members of ACOFOP explain that communities make much more effective resource 'guards' as they invest time and resources in controlling access to and activities in their concession areas. Protected areas in which communities do not have a management role are more vulnerable to degradation because official protection is less adequate. Other recent forthcoming research shows partial support for the position that community concessions are better than parks in inhibiting deforestation in the Petén, although a full explanation of differences in deforestation rates surely requires exploration of factors such as colonization history and variation in demographic pressure (Bray personal communication).
Other examples include Acre, where the rubber tapper movement helped propel a pro-forest state government into office and influenced federal policies. In Mamirauá, once boundary conflicts between communities were resolved and management practices defined, resident families became much more vigilant to intrusions by outsiders or violations of norms by neighbours. The forest management practised by these groups is not perfect, but clearly in these cases it has generated more positive results than contested landscapes or protected areas without community involvement have. In comparison to areas under indigenous management, Brazilian Amazonian forests in adjacent areas are significantly more degraded or completely transformed (Schwartzman et al. 2000; Nepstad et al. 2006). In Nicaragua, as members of $\mathrm{PCaC}$-Siuna gained more secure holdings and recognized that the frontier was closing they began burning less and becoming more interested in investing in cover crops and agroforestry to maintain the lands they held.

These four cases show persuasively that conservation and sustainable community livelihoods do not have to be contradictory. These grassroots movements indicate that communities can be effective collaborators in conservation, with highly positive impacts on biodiversity and poverty alleviation. As these grassroots groups develop and seek to take on more responsibility in forest management, their needs change. They seek greater autonomy in decision making. They seek to further develop their forest activities, by improving and extending their productive chains, or develop more integrated approaches to natural resource management. They also face the need to develop greater negotiating capacity in the increasingly complex resource politics of their regions. New kinds of technical assistance are needed to complement traditional approaches and to more effectively build local capacity for research, analysis and planning. Crucial conditions for this type of sustainable learning process include strengthened capacities of communities and their grassroots organizations to analyze, plan and represent their own interests in management for conservation and development (Taylor et al. 2007). 


\section{Conclusions}

A new actor in the conservation of protected areas is emerging in Latin America, the forest steward community. In the four case studies described here, communities have won legal access and management rights to forest resources. They are engaging in a range of timber and non-timber product activities that produce signs of significant positive conservation and local livelihood impacts. These communities are forming new collective organizations to govern and manage their resources, and are developing a growing network of alliances with other national and international groups with shared interests in conservation and development. Their secondary level organizations are showing significant capabilities to learn and adapt to changing environmental, social and political contexts. And they are participating more directly and on increasingly equal footing in the negotiation of the future of their forests.

These forest steward communities have emerged out of regions with histories of weak environmental governance, exacerbated by minimal state presence and intense competition for control of resources. In these regions, forest social movements were catalyzed by the establishment of conservation areas whose design initially overlooked community interests and directly threatened local livelihoods. In these cases, communities succeeded in developing consensus on the threats facing their interests, benefited from solid internal leadership, and demonstrated strong local commitment to taking the risk of organizing collectively to pursue new and largely unfamiliar forest management responsibilities. Key to their success thus far has been these forest social movements' capacity to form alliances with other social actors, within and from outside their regions. And crucially, these movements have benefited from external assistance efforts which have both laid the legal and technical foundations for effective community resource management and strengthened local capacities.
However, the future role of communities in forest management is not to be taken for granted. These forest steward communities and their organizations confront ongoing needs to adapt to dynamic local contexts. They face the prospect of uncertain or shifting future official support for their resource management role. How may the emergence and consolidation of forest steward communities be supported effectively from the outside? How may local capacities for autonomous action be strengthened without substituting for local initiative or creating unnecessary dependency? Forest steward communities require appropriate external support that can backstop them with skills and knowledge they do not possess, yet can also adapt to communities' own evolution and progressive assumption of new management responsibilities.

New models of external technical assistance need to be developed that can appropriately accompany the social and political processes underlying an effective role for forest steward communities. These non-traditional accompaniment models should not seek to replace more traditional assistance, which can be effective at particular stages of development of community resource management capability. Appropriately combining non-traditional and traditional assistance models poses a great challenge to all parties seeking to conserve threatened forests while ensuring viable local livelihoods.

The stakes are high for developing resource management models that will be effective in protecting the threatened forests of the global South. With appropriate support, forest steward communities show potential to become a cornerstone of broad-based efforts to sustainably manage natural resources for conservation and development. 


\section{References}

Alencar, E.F. 2002. Terra Caída: Encante, Lugares e Identidades. Doctoral Thesis, Universidade de Brasília (UNB), Brazil. [In Portuguese.] (Fallen Land: Charm, Place and Identity).

Asociación de Comunidades Forestales de Petén (ACOFOP). 2004. Carta Abierta al Sr. Presidente De La Republica De Guatemala, Lic. Oscar Bergar Perdomo, Magistrados de la Corte de Constitucionalidad y Miembros del Congreso January 26, 2004. [In Spanish.] (Open letter to the President of Guatemala, Mr. Oscar Berger Perdomo, Judges of the Constitutional Court and Members of Congress).

Asociación de Comunidades Forestales de Petén (ACOFOP). 2005. Representamos al Proyecto Forestal Comunitario más Grande del Mundo. http://www.acofop.org/ (4 Feb. 2005). [In Spanish.] (We represent the largest community forestry project in the world).

Assies, W. 1997. Going nuts from the rainforest: Non-timber Forest Products, forest conservation and sustainability in Amazônia. Thela Publishers, Amsterdam.

Bakx, K.S. 1988. From proletarian to peasant: Rural transformation in the State of Acre, 1870-1986. Journal of Development Studies 24 (2): 141-60.

Binswanger, H.P. 1991. Brazilian policies that encourage deforestation in the Amazon. World Development 19 (7): 1191-1205.

Bonis-Charancle, J.M., Michael, M., Akwah, G., Mogba, Z., Tiani, A.M., Lescuyer, G., Warne, R. and Greenberg, B. 2007. How the Community Options Analysis and Investment Tool (COAIT) increasing analytical capability and institutional capacity in community based natural resource management. Unpublished report to Innovative Resources Management, Washington, D.C.

Bray, D.B. and Anderson, A.B. 2005. Global Conservation Non Governmental Organizations and Local Communities: Perspectives on Programs and Project Implementation in Latin America. Working
Paper No. 1, Conservation and Development Series. Florida International University, Miami, FL.

Bray, D.B. and Merino Pérez, L. 2002. The Rise of Community Forestry in Mexico; History, Concepts, and Lessons Learned from Twenty-Five Years of Community Timber Production. The Ford Foundation, Mexico City, Mexico.

Bray, D.B., Merino Pérez, L. and Barry, D. (eds.) 2005. The Community Forests of Mexico: Managing for Sustainable Landscapes. University of Texas Press, Austin.

Caminoto, J. 2000. Governador doAcre promete manejo sustentável em Londres. O Estado de São Paulo. http: / /www.estado.estadao. com.br/editorias/2000/06/07/ger929. html (22 Mar. 2003). [In Portuguese.] (The Governor of Acre promises sustainable management in London).

Campbell, C.E. 1996. Forest, field and factory: changing livelihood strategies in two extractive reserves in the Brazilian Amazon. Ph.D. Dissertation, University of Florida, Gainesville.

Cavalcanti, T.J. 1994. Colonização no Acre: Uma Análise Socioeconômica do Projeto de Assentamento Dirigido Pedro Peixoto. Master's Dissertation, Universidade Federal do Ceará - Fortaleza, Brazil. [In Portuguese.] (Colonization in Acre: Socioeconomic analysis of the Pedro Peixoto directed settlement project).

Chapin, M. 2004. A Challenge to Conservationists. World Watch Magazine, November/December: 17-31.

Colfer, C.J.P. (ed.) 2005. The Complex Forest: Communities, Uncertainty and Adaptive Collaborative Management. Resources for the Future, Center for International Forestry Research, Washington, D.C.

Consejo Nacional de Areas Protegidas (CONAP). 1996. Plan maestro Reserva Biosfera Maya. Colección Manejo Forestal en la Reserva de la Biósfera Maya No. 2. CATIE, Turrialba, Costa Rica. [In Spanish.] (Master Plan for the Maya Biosphere Reserve. Forest 
Management in the Maya Biosphere Reserve Collection No.2).

Cordeiro, R. and De Castelar, R.F.F. 1988. Histórico do Projeto Seringueiro. http: / /www.cnsnet.org.br/news_ver. php?idnews $=24$ (8 Oct. 2005). [In Portuguese.] (History of the Seringueiro Project).

Cuellar, N. and Kandel, S. 2005. Analisis de Contexto: Del Programa Campesino a Campesino de Siuna: Oportunidades y Desafos en la Zona e Amortiguamiento de Bosawas, Nicaragua. PRISMA, San Salvador, El Salvador. [In Spanish.] (The Farmer-to-Farmer Programme of Siuna, Nicaragua: Context, accomplishments and challenges).

Duarte, E.C. 2003. O Processo de Formação do Espaço Regional nos Últimos 20 Anos: A Construção de um Modelo de Desenvolvimento Sustentável Para o Estado do Acre. Master's Dissertation, Federal University of Acre, Rio Branco. [In Portuguese.] (The Process of Formation of Regional Space in the Last 20 Years: The Construction of a Sustainable Development Model for the State of Acre).

Elías, S., Gellert, G., Pape. E. and Reyes, E. 1997. Evaluación de la sostenibilidad en Guatemala. FLACSO, Guatemala, Guatemala. [In Spanish.] (Evaluation of sustainability in Guatemala).

Fernandes, M.I. 1999. OPT noAcre:AConstrução de uma Terceira Via. Master's Dissertation, Universidade Federal do Rio Grande do Norte, Natal, Brazil. [In Portuguese.] (The PT in Acre: The construction of a third way).

Freire, P. 1970. Pedagogy of the Oppressed. Continuum, New York.

Gómez, I. and Méndez, V.E. 2005. Analisis de Contexto: el Caso de la Asociacion de ComunidadesForestales dePeten (ACOFOP). PRISMA, San Salvador, El Salvador. [In Spanish.] (Contextual Analysis: Association of Forest Communities of the Petén).

Governo do Estado do Acre - SEIAM. 2005. Política Florestal. http://www.seiam. ac.gov.br/index.php?option=com_conten t\&task=view\&id=14\&ltemid=15 (26 Oct. 2005). [In Portuguese.] (Forest Policy).

Grzybowski, C. 1989. O testamento do homen da floresta (Chico Mendes por ele mesmo). Fase, Rio de Janeiro. [In Portuguese.] (The testament of a forest man [Chico Mendes in his own words]).

Holt-Giménez, E. 2006. Campesino a Campesino: Voices from Latin America's Farmer to Farmer Movement for Sustainable Agriculture. Food First Books, Oakland, CA.

Instituto Brasileiro de Meio Ambiente (IBAMA). 2005. Reservas Extrativistas da Amazônia. http://www.ibama.gov. br/resex/amazonia.htm (19 Oct. 2005). [In Portuguese.] (Extractive Reserves of Amazonia).

Instituto de Desenvolvimento Sustentável Mamirauá (IDSM). 2000. ProManejo Proposta: Iniciativa Promissora - Manejo Florestal Comunitário na Várzea da Reserva de Desenvolvimento Sustentável Mamirauá. IDSM, Programa de Manejo Florestal Comunitário, Tefé, Amazonas. [In Portuguese.] (ProManejo Proposal: Promising Initiative - Community Forest Management in the Flooded Forests of the Mamirauá Sustainable Development Reserve).

Instituto de Desenvolvimento Sustentável Mamirauá (IDSM). 2001. Alternativas Econômicas. http://www.mamiraua.org. br/5-0.html. [In Portuguese.] (Economic Alternatives).

Instituto de Desenvolvimento Sustentável Mamirauá (IDSM). 2002. Manejo Florestal Comunitário na Várzea da Reserva de Desenvolvimento Sustentável Mamirauá: Relatório de Andamento da Implantação Semestral - Ano 2 Trimestre VII (08/02/02 - 09/05/02). Unpublished report. IDSM, Programa de Manejo Florestal Comunitário, Tefé, Amazonas: [In Portuguese.] (Community Forest Management in the Flooded Forests of the Mamirauá Sustainable Development Reserve (08/02/02 - 09/05/02)).

Instituto de Desenvolvimento Sustentável Mamirauá (IDSM-OS). 2004. Relatório Anual do Contrato de Gestão celebrado entre o MCT e o IDSM-OS. Exercício de 2003 IDSMOS, Tefé, Amazonas. [In Portuguese.] (Annual report for Management Contract between the MCT and IDSM-OS. 2003 activities).

Inoue, C.Y.A. 2003. Construção do Conceito de Regime Global de Biodiversidade e Estudo do Caso Mamirauá - O Papel da Comunidade 
Epistêmica da Biologia da Conservação em Experiências Locais que Visam Conciliar Conservação da Biodiversidade e Desenvolvimento Sustentável. Centro de Desenvolvimento Sustentável (DCS), Universidade de Brasília (UNB). DCS-UNB, Tese de Doutorad, Brasília. [In Portuguese.] (The Construction of a Concept of a Global Biodiversity Regime and Case Study of Mamirauá - The role of community epistemology of conservation biology in local experience that attempts to reconcile biodiversity conservation and sustainable development).

Kaimowitz, D. 2002. Resources, Abundance and Competition in the Bosawas Biosphere Reserve, Nicaragua. In: Halle, M., Matthew, R. and Switzer, J. (eds.) Conserving the Peace: Resources, Livelihoods and Security, 171-97. International Institute for Sustainable Development, Winnipeg, Canada.

Kainer, K., Schmink, M., Leite, A.C.P and Da Silva Fadell, M.J. 2003. Experiments in forest-based development in Western Amazônia. Society and Natural Resources 16 (10): 1-18.

Klooster, D. 2000. Institutional Choice, Community, and Struggle: A Case Study of Forest Co-Management in Mexico. World Development 28:1-20.

Mahar, D. 1989. Government policies and deforestation in Brazil's Amazon region. World Bank, Washington, D.C.

McShane, T.O. 2003. The Devil in the Detail of Biodiversity Conservation. Conservation Biology 17: 1-3.

Ministério do Desenvolvimento Agrário (MDA), Instituto Nacional de Colonização e Reforma Agrária (INCRA) and Superintendência Regional do INCRA no Acre (SR.14/AC). 2001. Relatório Final-Operação de Dados SIPRA 2000. MDA, INCRA, SR.14/AC, Rio Branco, Acre. [In Portuguese.] (Final Report - Operation of Data SIPRA 2000).

Ministério do Meio Ambiente (MMA) e Governo do Estado do Acre. 1999. Alternativas para o Desenvolvimento de Atividades Sustentáveis. Agenda Positiva do Acre. 2 julho de 1999. MMA, Rio Branco. [In Portuguese.] (Alternatives for the Development of Sustainable Activities).

Molnar, A. 2003. Forest Certification and Communities: Looking Forward to the Next
Decade. Forest Trends, Washington, D.C.

Nepstad, D., Schwartzman, S., Banberger, B., Santilli, M., Ray, D., Schlesinger, P., Lefebvre, P., Alencar, A., Prinz, E., Fiske G. and Rolla, A. 2006. Inhibition of Amazon deforestation and fire by parks and indigenous lands. Conservation Biology 20 (1): 65-73.

Nittler, J. and Tschinkel, H. 2005. Manejo Comunitario del Bosque en la Reserva Maya de la Biosfera de Guatemala: Proteccion Mediante Ganancias University of Georgia, Watkinsville, GA. [In Spanish.] (Community Forest Management in the Maya Biosphere Reserve of Guatemala: Protection through Profits).

Pasos, R. 2001. El Programa de Campesino a Campesino y la UNAG (Resultados de una Auditoria de Procesos). Unpublished consultant's report, Managua, Nicaragua. [In Spanish.] (The Farmer-to-Farmer Programme and the UNAG (Results of a Process Audit)).

Pasos, R. 2006. Gestión comunitaria de recursos naturales y modelos de acompañamiento técnico: Lecciones desde Centroamérica. Unpublished consultant's report, Managua, Nicaragua. [In Spanish.] (Community management of natural resources and models of technical accompaniment: Lessons from Central America).

PCaC-Siuna. Undated a. Historia Movimiento de Campesino a Campesino en Siuna. Programa Campesino a Campesino PCaC, Siuna, Nicaragua. [In Spanish.] (The History of the Farmer-to-Farmer Programme in Siuna).

PCaC-Siuna. Undated b. De Campesino a Campesino, Siuna Nicaragua. Programa Campesino a Campesino PCaC, Siuna, Nicaragua. [In Spanish.] (From Farmer to Farmer, Siuna, Nicaragua).

Queiroz, H. 2001. Reservas: Reserva de Desenvolvimento Sustentável Mamirauá. http: / / www.mamiraua.org.br/2-1-a.html. [In Portuguese.] (Reserves: Mamirauá Sustainable Development Reserve).

Radachowsky, J. 2004. Effects of Certified Logging on Wildlife in Community and Industrial Forest Concessions of Northern Guatemala. Unpublished report to Wildlife Conservation Society, Consejo Nacional de Areas Protegidas (CONAP), United States Agency for International Development 
(USAID) and Fortalecimiento Institucional en Políticas Ambientales (FIPA), Guatemala City.

Revkin, A. 1990. The burning season: The murder of Chico Mendes and the fight for the Amazon rain forest. Houghton Mifflin Company, Boston.

Roney, J., Kunen, J. and Donald, M. Undated. Evaluacion arqueológico. Unpublished Evaluation Report to United States Agency for International Development (USAID), Guatemala City. [In Spanish.] (Archaeological Evaluation).

Sandri, S. 2003. A assustadora década de 70: Os anos de fogo. In: Carvalho, C., Martins, E. and Alves, A. (eds.) Caderno: Povos da Floresta, 24-7. Secretaria Executiva do Comitê Chico Mendes, Rio Branco, Acre. [In Portuguese.] (The startling decade of the 70s: The years of fire. In: Notebook: Peoples of the Forest).

Schmink, M. and Wood, C.H. 1987. The 'Political Ecology' of Amazônia. In: Little, P. and Horowitz, M.M. (eds.) Lands at risk in the Third World, 38-57. Westview, Boulder, Colorado.

Schmink, M. and Wood, C.H. 1992. Contested Frontiers in Amazonia. Columbia University Press, New York.

Schwartzman, S., Moreira, A. and Nepstad, D. 2000. Rethinking tropical forest conservation: Perils in parks. Conservation Biology 14 (5): 1351-7.

Sociedade Civil Mamirauá (SCM), Conselho Nacional de Desenvolvimento Cientifico e Tecnológico/ Ministério da Ciência \& Tecnologia (CNPq/MCT) and Instituto de Proteção Ambiental do Estado do Amazonas (IPAAM). 1996. Mamirauá - Plano de Manejo. IPAAM, Manaus. http://www.mamiraua. org.br. [In Portuguese.] (Mamirauá Management Plan).

Souza, C.A.A. 2002. História do Acre: Novos temas, nova abordagem. M.M. Paim, Rio Branco. [In Portuguese.] (History of Acre: New themes, new treatment).

Stone-Jovicich, S., Amaral, P., Cronkleton, P., Fonseca, H. and Pires, A. 2007a. Acompanhamento Para O Manejo Florestal Comunitário Na Reserva De Desevolvimento Sustentável Mamirauá, Amazonas, Brasil. Center for International Forestry Research (CIFOR), Bogor, Indonesia. [In Portuguese.] (Accompaniment for Community Forest
Management in the Mamirauá Sustainable Development Reserve, Amazonas, Brazil).

Stone-Jovicich, S., Cronkleton, P., Amaral, P. and Schmink, M. 2007b. Acompanhamento Para O Manejo Florestal Comunitário No Projeto Cachoeira, Acre, Brasil. Center for International Forestry Research (CIFOR), Bogor, Indonesia. [In Portuguese.] (Accompaniment for Community Forest Management in the Cachoeira Project, Acre, Brazil).

Taylor, P.L. 2007. La Conservación, la Comunidad y la Cultura? Nuevas Direcciones para las Concesiones Forestales Comunitarias de la Biosfera Maya de Guatemala. Unpublished report to the Association of Forest Communities of Petén (ACOFOP). June, 2007. [In Spanish.] (Conservation, Community and Culture? New Directions for Community Forest Concessions in the Maya Biosphere Reserve of Guatemala).

Taylor, P.L. and Zabin, C. 2000. Neoliberal Reform and Sustainable Forest Management in Quintana Roo, Mexico: Rethinking the Institutional Framework of the Forestry Pilot Plan. Agriculture and Human Values 17: $141-56$.

Taylor, P.L., Cronkleton, P., Barry, D., StoneJovicich, S. and Schmink, M. 2007. If You Saw It with My Eyes: Collaborative Research and Assistance with Central American Forest Steward Communities. Center for International Forestry Research (CIFOR), Bogor, Indonesia.

Tropico Verde. 2005. El proyecto turistico Cuenca del Mirador y las concesiones forestales en la zona de uso multiple de la Reserva de la Biosfera Maya. Tropico Verde, Flores, Guatemala. [In Spanish.] (The Mirador Basin Tourism Project and the forest concessions in the multi-use zone of the Maya Biosphere Reserve).

United Nations Educational, Scientific and Cultural Organization (UNESCO). 1996. Reservas de biosfera: La estrategia de Sevilla y Marco Estatuario de la Red Mundial. UNESCO, Paris. [In Spanish.] (Biosphere Reserves: The Sevilla Strategy and the Statutory Framework of the Global Network).

United Nations Educational, Scientific and Cultural Organization (UNESCO). 2005. http: / /www.unesco.org/mab/br/focus/ 2002Sep/Bosawas.htm (18 Sept. 2005) 
White, A. and Martin, A. 2002. Who Owns the World's Forests? Forest Tenure and Public Forests in Transition. Forest Trends and Center for International Environmental Law, Washington, D.C.

Wildlife Conservation Society (WCS), International Resources Group (IRG), Proyecto FIPA/Guatemala and Consejo Nacional de Areas Protegidas (CONAP). 2003. Monitoreo de Incendios Forestales y Estimación de Superficies Quemadas, Reserva de Biósfera Maya, 2003. WCS, IRG, Proyecto FIPA and CONAP, Petén, Guatemala. [In Spanish.] (Monitoring of Forest Fires and Estimation of Burnt Area, Maya Biosphere Reserve, 2003).
Wildlife Conservation Society (WCS), International Resources Group (IRG), Proyecto FIPA/Guatemala and Consejo Nacional de Areas Protegidas (CONAP). 2004. Estimación de la Deforestación en la Reserva de Biosfera Maya, periodo 2003-2004. WCS, IRG, Proyecto FIPA and CONAP, Petén, Guatemala. [In Spanish.] (Estimation of Deforestation in the Maya Biosphere Reserve, 2003-2004).

Witoshynsky, M. 2002. Communities mobilize to control and build natural assets - Acre, Brazil: An Amazon State forges a sustainable future. In: Sustainable solutions: Building assets for empowerment and sustainable development, 86-91. Ford Foundation, New York. 


\section{CIFOR Occasional Paper Series}

1. Forestry Research within the Consultative Group on International Agricultural Research

Jeffrey A. Sayer

2. Social and Economical Aspects of Miombo Woodland Management in Southern Africa: Options and Opportunities for Research

Peter A. Dewees

3. Environment, development and poverty: A Report of the International Workshop on India's Forest Management and Ecological Revival

Uma Lele, Kinsuk Mitra and O.N. Kaul

4. Science and International Nature Conservation Jeffrey A.Sayer

5. Report on the Workshop on Barriers to the Application of Forestry Research Results

C.T.S. Nair, Thomas Enters and B. Payne

6. Production and Standards for Chemical Non-Wood Forest Products in China Shen Zhaobang

7. - Cattle, Broadleaf Forests and the Agricultural Modernization Law of Honduras: The Case of Olancho

- (Spanish edition) Ganadería, bosques latifoliaods y Ley de Modernizatción en Honduras: El caso de Olancho

William D. Sunderlin and Juan A.Rodriguez

8. High quality printing stock - has research made a difference? Francis S.P. Ng

9. - Rates Causes of Deforestation in Indonesia: Towards a Resolution of the Ambiguities

- (Indonesian edition) Laju dan Penyebab Deforestasi di Indonesia: Penelaahan Kerancuan dan Penyelesaiannya

William D. Sunderlin and Ida Aju Pradnja Resosudarmo

10. Report on Discussion Forum on Irformation Services in the Asia-Pacific and AGRIS/CARIS in the 21st Century and Asia-Pacific Regional Consultation Michael O. Ibach and Yvonne Byron

11. Capacity for Forestry Research in the Southern African Development Community

Godwin S. Kowero and Michael J. Spilsbury

12. Technologies for sustainable forest management: Challenges for the 21st century

Jeffrey A. Sayer, Jerome K. Vanclay and R. Neil Byron

13. Bosques secundarios como recurso para el desarrollo rural y la conservación ambiental en los trópicos de América Latina

Joyotee Smith, César Sabogal, Wil de Jong and David Kaimowitz

14. Cameroon's Logging Industry: Structure, Economic Importance and Effects of Devaluation

Richard Eba'a Aty

15. - Reduced-Impact Logging Guidelines for Lowland and Hill Dipterocarp Forests in Indonesia

- (Indonesian edition) Pedoman Pembalakan Berdampak Rendah untuk Hutan Dipterocarpa Lahan Rendah dan Bukit di Indonesia Plinio Sist, Dennis P. Dykstra and Robert Fimbel

16. Site Management and Productivity in Tropical Forest Plantations A. Tiarks, E.K.S. Nambiar and Christian Cossalter

17. Rational Exploitations: Economic Criteria and Indicators for Sustainable Management of Tropical Forests Jack Ruitenbeek and Cynthia Cartier

18. Tree Planting in Indonesia: Trends, Impacts and Directions Lesley Potter and Justin Lee

19. Le Marche des Produits Forestiers Non Ligneux de l'Afrique Centrale en France et en Belgique: Produits, Acteurs, Circuits de Distribution et Debouches Actuels Honoré Tabuna

20. Self-Governance and Forest Resources Elinor Ostrom

21. Promoting Forest Conservation through Ecotourism Income? A case study from the Ecuadorian Amazon region Sven Wunder

22. Una de Gato: Fate and Future of a Peruvian Forest Resource Wil de Jong, Mary Melnyk, Luis Alfaro Lozano, Marina Rosales and Myriam García

23. Les Approches Participatives dans la Gestion des Ecosystemes Forestiers d'Afrique Centrale: Revue des Initiatives Existantes Jean-Claude Nguinguiri

24. Capacity for Forestry Research in Selected Countries of West and Central Africa Michael J. Spilsbury, Godwin S. Kowero and F. Tchala-Abina

25. L'Ímpact de la Crise Economique sur les Populations, les Migration et le Couvert Forestier du Sud-Cameroun Jacques Pokam Wadja Kemajou and William D.Sunderlin

26. - The Impact of Sectoral Development on Natural Forest Conservation and Degradation: The Case of Timber and Tree Crop Plantations in Indonesia

- (Indonesian edition) Dampak Pembangunan Sektoral terhadap Konversi dan Degradasi Hutan Alam: Kasus Pembangunan HTI dan Perkebunan di Indonesia Hariadi Kartodihardjo and Agus Supriono
27. L'Impact de la Crise Économique sur les Systèmes Agricoles et le Changement du Couvert Forestier dans la Zone Forestière Humide du Cameroun

Henriette Bikié, Ousseynou Ndoye and William D.Sunderlin

28. - The Effect of Indonesia's Economic Crisis on Small Farmers and Natural Forest Coverin the Outer Islands

- (Indonesian Edition) Dampak Krisis Ekonomi Indonesia terhadap Petani Kecil dan Tutupan Hutan Alam di Luar Jawa

William D. Sunderlin, Ida Aju Pradnja Resosudarmo, Edy Rianto, Arild Angelsen

29. The Hesitant Boom: Indonesia's Oil Palm Sub-Sector in an Era of Economic Crisis and Political Change Anne Casson

30. The Underlying Causes of Forest Decline Arnoldo Contreras-Hermosilla

31. 'Wild logging': The rise and fall of logging networks and biodiversity conservation projects on Sumatra's rainforest frontier John F. McCarthy

32. Situating Zimbabwe's Natural Resource Governance Systems in History Alois Mandondo

33. Forestry, Poverty and Aid J.E. Michael Arnold

34. The Invisible Wand: Adaptive Co-management as an Emergent Strategy in Complex Bio-economic systems.

Jack Ruitenbeek and Cynthia Cartier

35. Modelling Methods for Policy Analysis in Miombo Woodlands

A. A Goal Programming Model for Planning Management of Miombo Woodlands

I. Nhantumbo and Godwin S. Kowero

B. A System Dynamics Model for Management of Miombo Woodlands Ussif Rashid Sumaila, Arild Angelsen and Godwin S. Kowero

36. How to Know More about Forests? Supply and Use of Information for Forest Policy

$K$. Janz and R. Persson

37. Forest Carbon and Local Livelihoods: Assessment of Opportunities and Policy Recommendations

Joyotee Smith and Sara J. Scherr

38. - Fires in Indonesia: Causes, Costs and Policy Implications

- (Indonesian edition) Kebakaran Hutan di Indonesia: Penyebab, Biaya dan Implikasi Kebijakan Luca Tacconi

39. Fuelwood Revisited: What Has Changed in the Last Decade? Michael Arnold, Gunnar Köhlin, Reidar Persson and Gillian Shepherd

40. Exploring the Forest-Poverty Link: Key concepts, issues and research implications Arild Angelsen and Sven Wunder

41. - Bridging the Gap: Communities, Forests and International Networks

- (French Edition) Communautés, forêts et réseauxinternationaux : des liaisons à renforcer

- (Spanish Edition) Cerrando la Brecha: Comunidades,Bosques y Redes Internacionales

Marcus Colchester, Tejaswini Apte, Michel Laforge, Alois Mandondo and Neema Pathak

42. Payments for environmental services: Some nuts and bolts Sven Wunder

43. Recent Experience in Collaborative Forest Management: A Review Paper Jane Carter with Jane Gronow

44. - Fighting forest crime and promoting prudent banking for sustainable forest management: The anti money laundering approach

- (Indonesian edition) Memerangi Kejahatan Kehutanan dan Mendorong Prinsip Kehati-hatian Perbankan untuk Mewujudkan

Pengelolaan Hutan yang Berkelanjutan: Pendekatan Anti Pencucian Uang Bambang Setiono and Yunus Husein

45. Forests and Human Health: Assessing the Evidence Carol J. Pierce Colfer, Douglas Sheil and Misa Kishi

46. Capturing Nested Spheres of Poverty: A Model for Multidimensional Poverty Analysis and Monitoring

Christian Gönner, Michaela Haug, Ade Cahyat, Eva Wollenberg, Wil de Jong, Godwin Limberg, Peter Cronkleton, Moira Moeliono, Michel Becker

47. Poverty and forests: Multi-country analysis of spatial association and proposed policy solutions William D. Sunderlin, Sonya Dewi, Atie Puntodewo

48. Logging for the ark Improving the conservation value of production forests in South East Asia

Lena Gustafsson, Robert Nasi, Rona Dennis, Nguyen Hoang Nghia,

Douglas Sheil, Erik Meijaard, Dennis Dykstra, Hari Priyadi,

Pham Quang Thu 


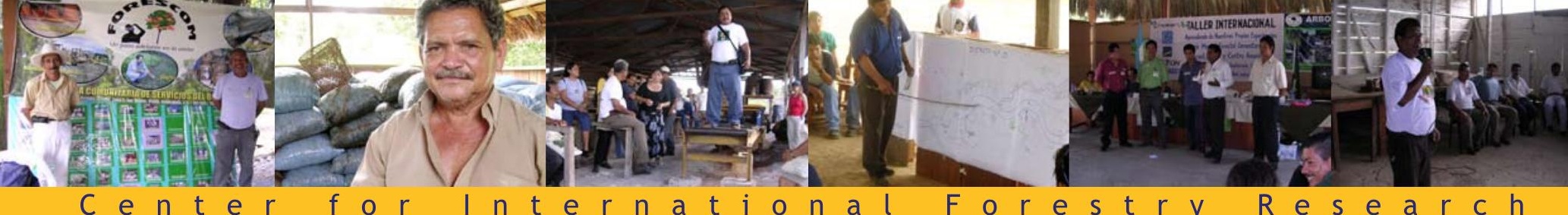

The CIFOR Occasional Paper series publishes research results that are particularly significant to tropical forestry. The content of each paper is peer reviewed internally and externally, and simultaneously published in print and on the web (www.cifor.cgiar.org/publications/papers).

To request a copy, please contact publications at cifor@cgiar.org

CIFOR is a leading international forestry research organisation established in 1993 in response to global concerns about the social, environmental, and economic consequences of forest loss and degradation. CIFOR is dedicated to developing policies and technologies for sustainable use and management of forests, and for enhancing the well-being of people in developing countries who rely on tropical forests for their livelihoods. CIFOR is one of the 15 centres of the Consultative Group on International Agricultural Research (CGIAR). With headquarters in Bogor, Indonesia, CIFOR has offices in Brazil, Bolivia, Burkina Faso, Cameroon, Ethiopia, India, Zambia and Zimbabwe, and it works in over 30 other countries around the world. 